\title{
Continuidad y transformaciones de modelos pedagógicos en la École Polytechnique (1867-1910)
}

\section{Estelle Thibault}

École Nationale Supérieure d'Architecture ENSA,

Paris-Belleville (Francia)

\section{Traductores:}

Andrés Ávila-Gómez

Université Paris I Panthéon-Sorbonne (Francia)

Diana Carolina Ruiz

Université Paris IV Paris-Sorbonne (Francia)

Thibault, E. (2018). Continuidad y

rransformaciones de mode-

los pedagógicos en la École

Polytechnique (1867-1910)

[Continuité et transformations

des dispositifs pédagogiques à

I'École Polytechnique (1867-

1910)] (Andrés Ávila-Gómez

y Diana Carolina Ruiz, trads.

(original en francés, 2011).

Revista de Arquitectura (Bo-

gotá), 20(2), I10-126. doi:

http://dx.doi.org/10.14718/

RevArq.2018.20.2.2149

http://dx.doi.org/10.14718/Revarq.2018.20.2.2149

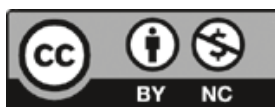

\section{Estelle Thibault}

Arquitecta D.P.L.G.

DEA en Proyecto arquictónico y urbano, ENSA Paris-Belleville.

Doctora en Arquitectura, Université Paris 8.

H.D.R. (Habilitación para dirigir tesis doctorales), Université Paris-Est.

Profesora titular en los campos de la teoría y de la práctica del proyecto arquitectónico y urbano: ENSA Paris-Belleville.

Directora del Institut Parisien de Recherche - Architecture, Urbanistique, Société (IPRAUS). http://www.umrausser.cnrs.fr/estelle-thibault

(1) https://orcid.org/0000-0002-2509-5857

estelle.thibault@paris-belleville.archi.fr

\section{Andrés Ávila-Gómez}

Arquitecto, Universidad de Los Andes (Colombia).

Magíster en Urbanismo, Universidad Nacional de Colombia.

Magíster en Ville, architecture, patrimoine, Université Paris 7 Diderot \& ÉNSA Paris-Val de Seine. Doctorando en Histoire de l'Art, Université Paris I Panthéon-Sorbonne (École doctorale 44 I). Investigador asociado del Centre de Recherche HiCSA - Histoire culturelle et sociale des arts, Université Paris I Panthéon-Sorbonne.

https://univ-paris I .academia.edu/AndresAvila (D) http://orcid.org/0000-0003-3883-2737

andresavigom@gmail.co

\section{Diana Carolina Ruiz}

Profesional en Langues Etrangères Appliquées, U. Paris IV Paris-Sorbonne.

Máster en Études Hispaniques et Hispano-Américaines. U. Paris IV Paris-Sorbonne.

Traductora para revistas de arquitectura, patrimonio e historia del arte (Atrio; Dearq; Apuntes; Academia XXII)

(D) http://orcid.org/0000-000I-5524-0456

karorr2002@gmail.com

\section{Resumen}

Entre las instituciones europeas cuyos sistemas pedagógicos influenciaron profundamente la enseñanza de la arquitectura y de la construcción durante el siglo XIX y comienzos del siglo XX, la École Polytechnique (fundada en París en I794) ocupó un lugar central, gracias a la labor pedagógica desarrollada por figuras como Jean Nicolas Louis Durand, Léonce Reynaud y Gustave Umbdenstock, cuyos cursos en la École fueron publicados y alcanzaron amplio reconocimiento en el ámbito académico internacional. Es a partir de esto que se estudian diversos aspectos de la labor docente de un discípulo de Reynaud: el ingeniero Fernand de Dartein (1838-1912), quien ocupó también la cátedra titular de arquitectura en la École Polytechnique, entre 1870 y 1910. Para ello, se analizan los planes de estudio de los cursos impartidos por Dartein; ejemplos de las modalidades de transmisión aplicadas (ejercicios gráficos y cuadernos de notas de alumnos); y escritos del propio Dartein, a través de los cuales es posible identificar elementos de ruptura y de continuidad que caracterizaron la enseñanza de la arquitectura en una época en la cual se acentuaban las diferencias entre el aprendizaje artístico de la composición arquitectónica y la integración de la dimensión técnica.

Palabras clave: arquitectura, plan de estudios, pedagogía, método de enseñanza, clase magistral, dibujo, geometría, historia de la arquitectura.

\section{Continuity and transformations of teaching models at the École Polytechnique (1867-1910)}

\section{Abstract}

Among the European institutions whose pedagogical systems profoundly influenced the teaching of architecture and construction during the nineteenth and early twentieth centuries, the École Polytechnique (founded in Paris in 1794) occupied a central place, thanks to the pedagogical work developed by scholars such as Jean Nicolas Louis Durand, Léonce Reynaud, and Gustave Umbdenstock, whose courses at the École were published and achieved wide recognition in the international academic field. Based on this, this paper analyzes various aspects of the teaching work of a disciple of Reynaud: the engineer Fernand de Dartein (1838-1912), who also held the position of chair of architecture at the École Polytechnique between 1870 and 1910. To this effect, it examines study plans from the courses taught by Dartein; examples of the transmission modes applied (graphic exercises and student notebooks); and Dartein's own writings, through which it is possible to identify elements of rupture and continuity that characterized the teaching of architecture in an era when there were prominent differences between the artistic learning of architectural composition and the integration of technical dimensions.

Keywords: Architecture, study plan, pedagogy, teaching methods, master class, drawing, geometry, architectural history.

Continuidade e transformações de modelos pedagógicos na École Polytechnique (1867-1910)

\section{Resumo}

Entre as instituições europeias, cujos sistemas pedagógicos influenciaram profundamente o ensino da arquitetura e da construção durante o século XIX e princípios do século XX, a École Polytechnique (fundada em Paris, em I794) ocupou um lugar central, graças ao trabalho pedagógico desenvolvido por figuras como Jean-Nicolas-Louis Durand, Léonce Reynaud e Gustave Umbdenstock, cujos cursos na Ecole foram publicados e alcançaram amplo reconhecimento no âmbito acadêmico internacional. É a partir disso que diversos aspectos do trabalho docente de um discípulo de Reynaud são estudados: o engenheiro Fernand de Dartein (1838-1912), que também ocupou a cadeira titular de arquitetura na École Polytechnique, entre I870 e 1910. Assim, foram analisados os planos de estudo dos cursos ministrados por Dartein; exemplos das modalidades de transmissão aplicadas (exercícios gráficos e cadernos de notas de alunos); e escritos do próprio Dartein, através dos quais é possível identificar elementos de ruptura e de continuidade que caracterizaram o ensino da arquitetura em uma época na qual as diferenças entre a aprendizagem artística da composição arquitetônica e da integração da dimensão técnica eram acentuadas.

Palavras-chave: arquitetura, plano de estudos, pedagogia, método de ensino, aula magistral, desenho, geometria, história da arquitetura. 


\section{Introducción}

¿De qué manera pueden ser transformadas las pedagogías arquitectónicas por las evoluciones que afectan las realidades profesionales de los ingenieros? ¿Cómo se producen los ajustes en estos campos y cuáles son las temporalidades que se presentan? El caso de la enseñanza de la arquitectura en la École Polytechnique permite considerar las lentas modificaciones ocurridas, y estudiar las continuidades o rupturas engendradas durante la transición gradual entre un profesor y otro. En la segunda mitad del siglo XIX se produjo la consolidación de un sistema pedagógico extremadamente codificado y que oponía resistencia frente a la marginalización progresiva de la arquitectura en las formaciones impartidas en la École Polytechnique. El inicio del siglo XX trajo consigo una mutación más radical que abarcó al mismo tiempo los contenidos y las modalidades prácticas de la transmisión.

Los estudios acerca de la historia de la École Polytechnique revelan cómo la prioridad dada durante sus primeros años de existencia a las disciplinas relacionadas con la geometría y con el dibujo fue puesta rápidamente en entredicho ante la creciente importancia de las ciencias aplicadas $^{1}$. Los debates en torno al lugar que debía ocupar la arquitectura reflejaban las dificultades que afrontaba la institución para reformarse, debatiéndose ante la fidelidad debida a los principios fundadores que situaban las disciplinas gráficas en el núcleo del sistema pedagógico, o ante la necesidad de reconquistar su preeminencia frente a la competencia con otros establecimientos científicos. Según Antoine Picon, desde 1830 la pérdida de influencia de la arquitectura había prefigurado la "liquidación definitiva de la herencia del ingeniero artista" (Picon, 1992), a la cual se asistió a lo largo del siglo.

Aunque diversos estudios han sido consagrados a los cursos de arquitectura impartidos sucesivamente en la l'École Polytechnique por Jean Nicolas Louis Durand (1760-1834) entre 1797 y 1834², por Léonce Reynaud (1803-1880) entre 1837 y $1867^{3}$, y por Gustave Umbdenstock (18661940) entre 1919 y $1937^{4}$, encontramos que en cambio, el curso impartido por el ingeniero Fernand de Dartein ${ }^{5}$ (1838-1912) no ha llamado de manera similar la atención de los investigadores: el poco interés que ha despertado el curso de

1 Ver Belhoste, Dahan-Dalmedico y Picon (1994), y Shinn (1980).

2 Ver Szambien (1984)

3 Ver "La doctrine de Léonce Reynaud, entre rationalisme structurel et système des beaux arts" (Picon, 1992a); "Apprendre à concevoir les gares: I'enseignement de Léonce Reynaud" (Picon, 1992b); y "Entre rationalisme et éclectisme, l'enseignement d'architecture de Léonce Reynaud" (Guigueno y Picon, 1996).

4 Ver "Gustave Umbdenstock, professeur d'architecture" (Vigato, 1996).

5 Ver la síntesis biográfica sobre Dartein realizada por Simona Talenti para el Allgemeines Künstlerlexikon (2000).
Dartein entre los investigadores se explica justamente porque este ingeniero no publicó nunca sus lecciones ${ }^{6}$, como sí lo hicieron sus colegas.

Más aun, Dartein reivindicó una postura como "simple continuador" (Dartein, 1874) de su maestro Reynaud, asegurando hasta principios del siglo XX la transmisión del curso heredado a aquel ${ }^{7}$. Por eso, Dartein aparece en las historias sobre la École Polytechnique como una figura de segundo nivel y observador atento del trabajo de sus predecesores, así como fiel sucesor y primer biógrafo de Reynaud, en su texto Léonce Reynaud. Sa vie et ses œuvres par l'un de ses élèves (1885). De hecho, como lo ha señalado Simona Talenti, Fernand de Dartein fue más conocido como historiador que como profesor de arquitectura (Talenti, 2000) gracias a su publicación Étude sur l'architecture lombarde et sur les origines de l'architecture romano-byzantine (Dartein, 1865). Talenti ha estudiado la labor docente de Dartein, ya no desde la perspectiva de la pedagogía del proyecto sino como un curso de historia de la arquitectura, con lo cual contribuyó en aquel momento a la emergencia de esta disciplina (Talenti, 2000), como también lo hizo su colega Auguste Choisy (1841-1909). Dartein, quien había sido nombrado inicialmente en 1886 répétiteur de Reynaud, para ser luego profesor durante 44 años, fue sin embargo la figura que aseguró la enseñanza de la arquitectura en la École Polytechnique durante el periodo más extenso. Es precisamente en este rol de continuador sobre el cual se centra nuestra atención, para mostrar la forma como Dartein logró defender y perpetuar el método pedagógico concebido por Reynaud, a pesar de las revisiones hechas a los programas: desde una postura abiertamente conservadora, invocó siempre la reputación de dicha enseñanza como principal argumento para mantener la carga horaria destinada a la arquitectura. Dos informes redactados por Dartein, el primero de ellos en $1874^{8}$-momento en el cual abogó en contra de la reducción de las horas destinada a la enseñanza de la arquitectura-, y el segundo en

6 La École des Ponts et Chaussées produjo una publicación pedagógica sobre granjas metálicas (Dartein, 1891-1893). En lo concerniente a sus cursos en la École Polytechnique, solamente se produjo una versión realizada con el método de impresión de la autographie para su último año de enseñanza en 1909.

7 Sobre las continuidades con las asignaturas de sus predecesores, verel artículo de Szambien y Talenti, "Durand, Quaet-Faslem et Dartein ou I'influence européenne de Durand" (1996), y el artículo de Savorra, "Une storia per gli ingegneri. Corrispondenze e continuità tra Léonce Reynaud, Fernand de Dartein e Auguste Choisy" (2005). Igualmente, son citados algunos elementos importantes en Composition non composition. Architecture et théories xixe-xxe siècles (Lucan, 2009, pp. 40-46).

8 Titulado: À Messieurs les membres du Conseil de perfectionnement. Observations sur le cours d'architecture de l'École Polytechnique et sur le programme de ses leçons. 


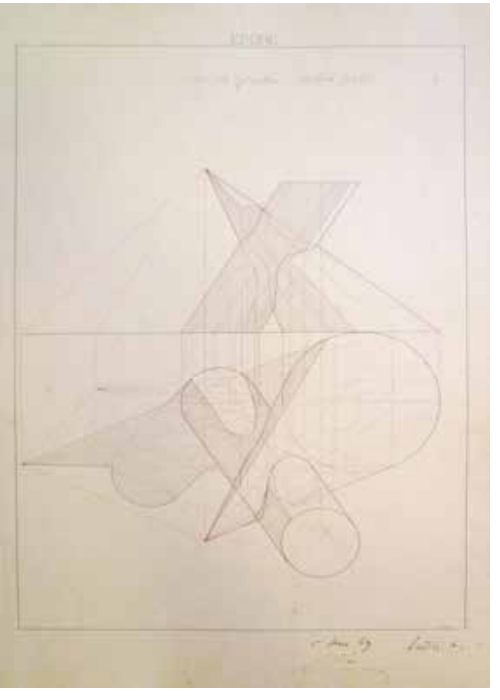

(A) Figura 1. Boceto de geometría descriptiva hecho en el Lycée Saint-Louis en 1869, presentado por Paul Londie para la admisión en la École Polytechnique

Fuente: Archivos de la École Polytechnique (AEP).

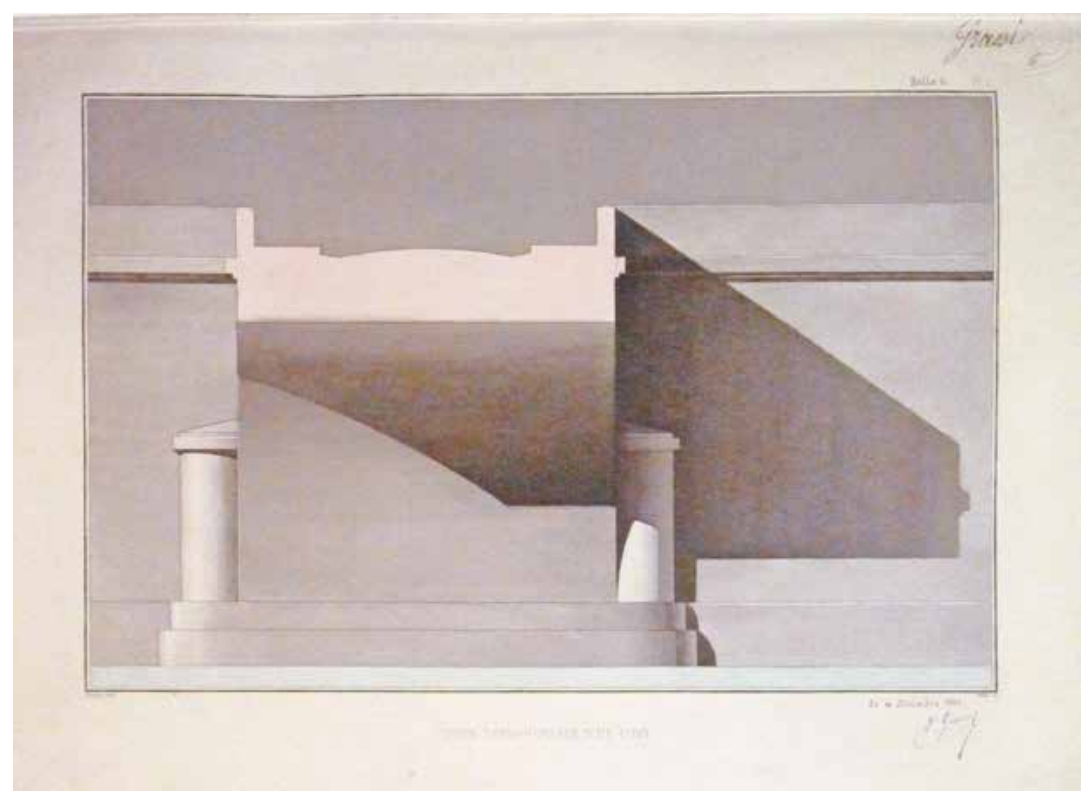

3igura 2. "Corte transversal de un puente": ejercicio de aguada del alumno Ernest Grassi, año 1867-1868 Fuente: Archivos de la École Polytechnique (AEP). $1908^{9}$-cuando se opone a la supresión total del curso-, son un testimonio de su resistencia ante las inevitables reformas que acechaban a la École Polytechnique al comenzar el siglo XX.

Diversos estudios han abordado el periodo posterior al de Dartein, particularmente sobre la formación impartida por el arquitecto Gustave Umbdenstock, quien fuera répétiteur a partir de 1901, chargé de cours en 1913 y posteriormente profesor titular entre 1919 y 1937; pero los análisis se han concentrado en los dos volúmenes de su Cours d'architecture, y más exactamente en la publicación final hecha en $1930^{10}$. Dichos análisis han pasado por alto, no solamente la evolución que se constata en las versiones sucesivas de dicha publicación, sino también las continuas modificaciones que afectaron el programa de esta asignatura. La génesis de este curso, y los debates que lo rodearon, resultan bastante esclarecedores para interpretar simultáneamente la evolución de contenidos y los métodos pedagógicos. En 1910, cuando Dartein decidió jubilarse, Umbdenstock heredó en efecto una asignatura caduca y amenazada con ser suprimida, despojada de su componente gráfico y degradada a la forma de simples "conferencias": era absolutamente necesario reinventarla para insuflarle validez.

Los estudios sobre historia de la pedagogía han señalado la necesidad de examinar el contexto de las prácticas didácticas, ya sea a través de la reconstitución del rol de la transmisión oral o por medio del análisis de los tipos de

9 Titulado: “Ä Messieurs les membres du conseil de l'École Polytechnique. Observations tendant au maintien du cours d'architecture dont la suppression ou la transformation en conférences est proposée par une dépêche du 17 juillet 1908 adressée par Monsieur le général inspecteur permanent des écoles militaires à monsieur le général commandant de l'École Polytechnique».

10 Sobre Gustave Umbdenstock, ver el artículo de Vigato, "Gustave Umbdenstock, professeur d'architecture" (1996), así como el texto del mismo autor, titulado "Gustave Umbdenstock, architecture, polémique et tradition" (1994). Otros elementos importantes sobre Umdenstock aparecen en: La Géométrie des émotions. Les esthétiques scientifiques de l'architecture en France 1860-1950 (2010). ejercicios efectuados por los alumnos ${ }^{11}$. Ante la ausencia de publicaciones del curso de Fernand de Dartein, se hace indispensable el recurso a otras fuentes, y por ello, el Traité d'architecture de Léonce Reynaud es una referencia esencial. Los archivos de la École Polytechnique dan buena cuenta de las evoluciones de los programas, de las reflexiones a propósito del equilibrio debido entre las diferentes asignaturas, y también de los debates ocurridos en el seno del Consejo de Perfeccionamiento. La conservación tanto del material redactado por los profesores para sus cursos como de ciertos ejercicios desarrollados por alumnos, permite aproximarse y entender la naturaleza concreta de los métodos pedagógicos empleados. Restituir de esta manera la realidad de la transmisión, utilizando otras fuentes diferentes a las publicaciones de los profesores, permite comprender aún mejor el rol jugado por dichas obras -especialmente el Traité d'architecture de Léonce Reynaud- en la formación arquitectónica de los ingenieros.

\section{La arquitectura en el sistema educativo}

\section{La importancia del conocimiento gráfico}

En el plan de estudios de la École Polytechnique durante las décadas de 1860 y 1870, las asignaturas basadas en la práctica del dibujo, aunque aparecían con menor fuerza que como había ocurrido durante los primeros años de la institución ${ }^{12}$, ocupaban todavía un lugar fundamental, si bien las asignaturas científicas en pleno desarrollo -física, química- les disputaban su presencia en los horarios de estudios, y coexistían igualmente con algunos cursos de literatura, de historia y de ale-

11 Ver los trabajos sobre historia de la educación realizados por el Institut National de Recherche Pédagogique, especialmente Une histoire de l'école. Anthologie de l'éducation et de l'enseignement en France xviiie-xxe siècle (2010).

12 Ver el texto de Joël Sakarovitch, "La Géométrie descriptive, une reine déchue" (1994). 


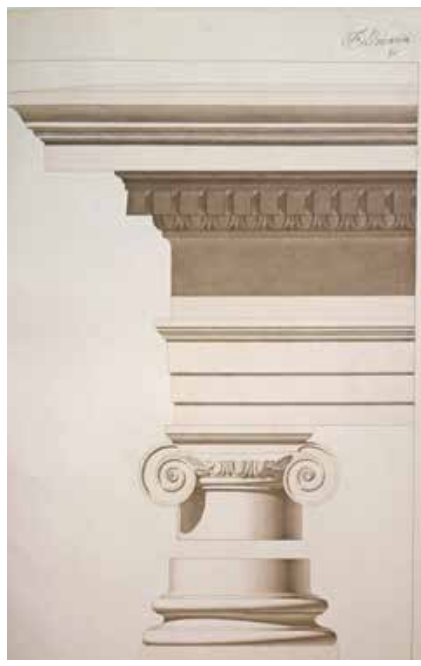

A Figura 3. Ejercicio de aguada "Base, capitel y entablamento", año 1866-1867 Fuente: Archivos de la École Polytechnique (AEP)

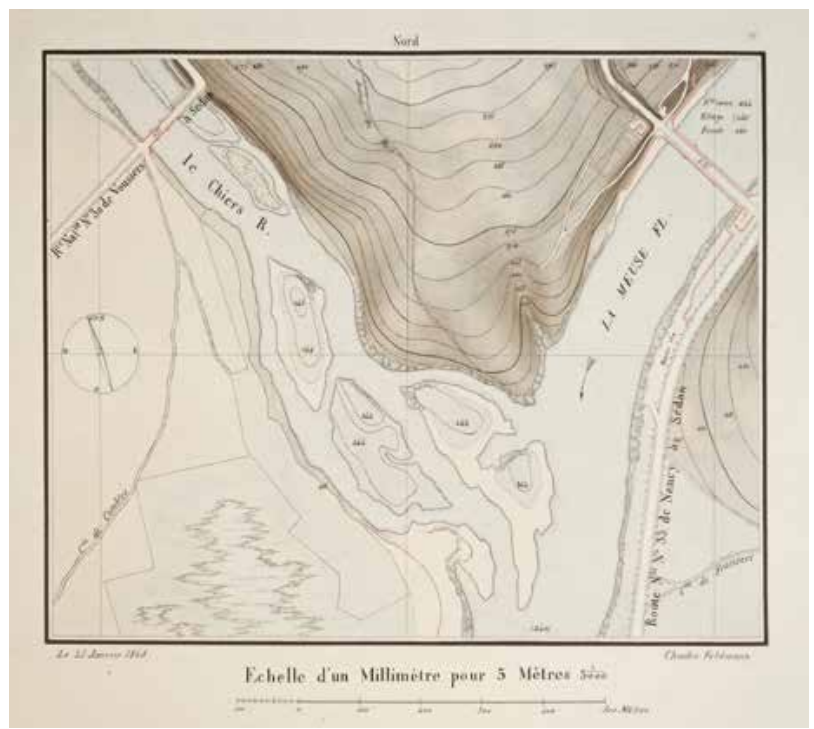

(A) Figura 4. Cartografía en aguada, alumno Charles Feldmann, 1868 Fuente: Archivos de la École Polytechnique (AEP). mán destinados a compensar la orientación científica con una aportación cultural ${ }^{13}$.

La formación en arquitectura hacía parte de aquellas disciplinas relacionadas con el dibujo que se ocupan de la descripción de objetos en el espacio, conectando la geometría, la concepción técnica y las bellas artes. Dentro del espíritu que presidió la fundación de la École Polytechnique, el desarrollo de la aptitud gráfica se erigió como un elemento constitutivo de la formación del ingeniero según una concepción sobre el dibujo apoyada en conocimientos matemáticos -la geometría descriptiva heredada de Garpard Monge (1746-1818) - y enriquecida por una sensibilidad artística latente. La arquitectura era vista como un pivote esencial entre el dominio de la descriptiva y el tránsito hacia una dimensión no solamente artística sino también cultural e histórica.

Es importante precisar que la École Polytechnique impartía en dos años una enseñanza básica que preparaba al alumno para las diferentes escuelas de aplicación propuestas: este espíritu inducía al carácter generalista del sistema de cursos, y así el alumno ingeniero era incitado a "aplicar" más adelante y en función de las preferencias escogidas, aquellos conocimientos ya adquiridos desarrollando en paralelo competencias más específicas. En dicha progresión, efectuada desde la "teoría" hacia la aplicación, el curso de arquitectura se consolidó por largo tiempo en el segundo año de estudios beneficiándose de la sólida formación impartida en geometría descriptiva y en técnicas gráficas. Los exámenes de admisión de la École Polytechnique revisaban las aptitudes de los candidatos que, en presencia de los examinadores, debían realizar: un diseño geométrico (Figura 1), una aguada en tinta china de acuerdo con un modelo suministrado, y la copia de un modelo sombreada en lápiz; todo ello acompañado de la presentación

13 Sobre este tema, ver el texto de Sakarovitch, "Auguste Choisy, Engineering Student: a Technical Training with a Pinch of Human and Social Sciences" (2009). de un dossier compuesto por bocetos y ejercicios de aguadas elaborados durante el año anterior ${ }^{14}$.

Durante el primer año, aquellos prerrequisitos eran fortalecidos con una enseñanza de la descriptiva que ejercitaba al alumno en el dominio de las proyecciones geometrales, oblicuas, perspectivas y axonométricas. Los bocetos que inicialmente eran de orden abstracto, se iban aplicando poco a poco a objetos concretos, piezas de máquinas o elementos de la construcción. Los ejercicios de aguadas forjaban igualmente en ese primer año, una sensibilidad hacia el arte de construir tomando regularmente como temas: el corte de un puente (Figura 2), la cimentación de un palacio romano o más tarde los detalles de capiteles dóricos y jónicos ${ }^{15}$ (Figura 3).

Estas formaciones gráficas continuaban durante el segundo año con la iniciación a la arquitectura propiamente dicha, y, paralelamente, la enseñanza de la estereotomía prolongaba la práctica de la geometría descriptiva aplicada a elementos de construcción, detalles de escaleras, aparejos de mampostería o montajes de estructuras.

La aptitud gráfica ejercitada a través del dibujo y la aguada se manifestaba igualmente en otras escalas, como por ejemplo, en aquellas asignaturas en las cuales era necesario representar la topografía (Figura 4) o el dibujo de máquinas ${ }^{16}$ (Figura 5).

14 Ver especialmente: los Programmes des connaissances exigées pour l'admission à l'École Impériale Polytechnique en 1863 arrêtés par le Conseil de Perfectionnement et approuvés par le Ministère de la guerre (1863), y el texto de Belhoste, "Anatomie d'un concours. L'organisation de l'examen d'admission à l'École Polytechnique de la Révolution à nos jours" (2002).

15 Estos ejercicios variaban muy poco: por ejemplo, con dieciséis años de intervalo, los alumnos Kretz (X 1850) y Feldmann (X 1866) realizaron exactamente las mismas aguadas ("cimientos del Palacio de la Cancillería en Roma", "corte transversal de un puente", "capitel y entablamento dóricos del Teatro de Marcellus en Roma", "base, capitel y entablamento dóricos del Tetro de Marcellus en Roma"). Archivos de la École Polytechnique (AEP).

16 El curso de "máquinas" estuvo dominado inicialmente por una orientación geométrica $-y$ se fue transformando poco a poco en una asignatura de "mecánica"-, integrando un trabajo gráfico consecuente que incluía la realización de planos 
Aquellas prácticas en donde primaba la descripción geométrica eran luego complementadas por la práctica más "artística" del dibujo de rostros y de paisajes, que hasta la década de 1880 se enseñó principalmente mediante la copia de estampas. De esta manera, desde la abstracción geométrica de la descriptiva hasta la expresión artística, los ejercicios de arquitectura se combinaban con un amplio conjunto de trabajos gráficos $^{17}$.

\section{"Arquitectura" frente a "construcción"}

En un informe enviado en 1874 al Consejo de perfeccionamiento de la École, Dartein subrayaba la diferencia entre el curso de "arquitectura" y un curso de "construcción" (Dartein, 1874), por cuanto esa distinción que podía parecer paradójica a primera vista en una escuela de ingenieros, resultaba entonces esencial para comprender las futuras orientaciones y las evoluciones de dicha formación. Dartein insistía en la necesidad de una definición artística, cultural e histórica de la composición arquitectónica que se situara por encima de las soluciones técnicas o programáticas más específicas. En este sentido, el profesor recordaba la manera como los cursos de "construcción" inicialmente presentes junto a la arquitectura en el plan de estudios de la École Polytechnique, habían sido suprimidos desde 1810 tras haber sido considerados de la competencia de las escuelas de aplicación, con lo cual se reservó la "arquitectura" para los años iniciales. En efecto, la orientación más importante precedía tanto la profundización en lo constructivo, como también la especificidad de los programas particulares de edificios.

La formación básica en arquitectura constituía el lugar para un "aprendizaje del gusto" que resultaba por ende "útil en todas las áreas" (Dartein, 1874), independientemente de la orientación posterior del alumno. Dicha formación inicial se caracterizó por un enfoque del arte del dibujo considerado como "general y superior a los diferentes tipos particulares" y capaz, en últimas, de fomentar la invención ante los "casos difíciles, nuevos o imprevistos" (Dartein, 1874, p. 4). Tal carácter generalista no impidió una articulación privilegiada con el plan de estudios de la École des Ponts et Chaussées, ya que al igual que Léonce Reynaud antes que él, Fernand de Dartein dictó clases en las dos instituciones con lo cual garantizó una continuidad entre la enseñanza básica y el desarrollo de competencias precisas. Más adelante veremos cómo la distinción entre "arquitectura" y "construcción", sobre la cual se

de engranajes. Sobre la evolución de los cursos de máquinas, ver el artículo de Jean-Yves Dupont, "Le cours de machines à I'École Polytechnique, de sa création jusqu'en 1850" (2000).

17 Ver los programas de estudios en: Programmes de l'enseignement intérieur de l'École Impériale Polytechnique pour I'année 1860-1861 (1861). apoyaba el argumento de Dartein, resulta bastante frágil, en la medida en que su enseñanza conjugaba estrechamente las nociones de composición y de construcción.

\section{La continuidad de una formación: de Reynaud a Dartein, 1850-1880}

La reforma orquestada en 1850 por la comisión Le Verrier tendía a restituir el valor a las disciplinas graficas debilitadas en las anteriores revisiones de los programas (Belhoste, Dahan-Dalmedico, Picon, 1994, pp. 27-29), y propiciaba una situación muy favorable para la enseñanza de la arquitectura, situación que Dartein vivió en calidad de alumno de Reynaud durante el año 1856-1857, y que se mantuvo hasta 1875. La transición en el relevo de Reynaud a Dartein se efectúo con total continuidad: en 1874, Dartein afirmaba impartir "el curso instituido por Reynaud" y en el cual no habría introducido sino algunos "sutiles cambios" (Dartein, 1874, p. 8). Su labor docente perfecciona un modelo pedagógico instaurado desde los orígenes de la École, asociando las clases magistrales y un conjunto de ejercicios gráficos.

\section{Los contenidos del curso: las clases magistrales en el auditorio}

La clase magistral, cuyos volúmenes del Traité d'architecture ${ }^{18}$ constituyen una versión más desarrollada, se consolidó en 1850 en torno a dos partes constituidas cada una por veinte lecciones: la primera consagrada a "elementos de edificios" y la segunda a la "combinación de elementos y composición de los edificios" (ver anexo 1). Esta clasificación -tomada de Jean Nicolas Louis Durand- estructuró un gran número de cursos de arquitectura y de construcción impartidos a lo largo del siglo XIX ${ }^{19}$. Dartein, sin embargo, llamaba la atención sobre el hecho de que esta clasificación bipartita constituía la única herencia de Durand, transmitiendo así las reservas manifestadas por Reynaud con respecto a la teoría "pretendidamente racional" desarrollada por Durand en el Précis des leçons (Dartein, 1885). Reynaud, en efecto, redirecciona los "elementos" de Durand hacia una definición constructiva mejor formulada, como se aprecia en el primer volumen de su Traité d'architecture en el cual privilegió la denominación "Art de bâtir" (Arte de construir).

18 El Traité d'architecture consta de 2 volúmenes de texto y 2 volúmenes de láminas. Los volúmenes de texto corresponden a la asignatura dictada por Reynaud, de la cual retoman la estructura. En la introducción Reynaud afirma que la publicación era un complemento del curso oral, mucho más conciso, en el cual introducía nociones que le eran útiles a la arquitectura pero que eran abordadas también en la enseñanza de otras disciplinas diferentes a la suya. Ver el "Préface", vol. 1, p. V.

19 Ver al respecto los textos de Valérie Nègre titulados: "Architecture et construction dans les cours de l'École Centrale des Arts et Manufactures (1833-1864) et du Conservatoire National des Arts et Métiers (1854-1894)" (2011b), y "L'enseignement de l'architecture au Conservatoire National des Arts et Métiers (1854-1971)" (2011a). 
La sección sobre los "elementos" aborda sucesivamente el empleo de la piedra, de la madera y finalmente del metal: cada secuencia comienza con las características de los materiales y los principios que inciden en su utilización, para describir a continuación los elementos arquitectónicos (muros, columnas, arcos...) destacando la interacción entre la dimensión técnica y la dimensión estética. Las lecciones que tratan sobre la piedra, que además integran la presentación de los órdenes, arcos y bóvedas (doce lecciones en el año 1874-1875), son las más desarrolladas por cuanto contrariamente a aquellas consagradas a la madera o al metal, estas incorporan el análisis histórico apoyándose en un corpus de obras de la Antigüedad y del Renacimiento.

La segunda parte se subdivide en dos series. La primera de ellas trata sobre las principales "combinaciones" (pórticos, vestíbulos, escaleras, salas abovedadas y planas) desde una perspectiva que implica la comparación de numerosos ejemplos históricos. La segunda serie se refiere a la composición de edificios, y abre con la exposición de un método idóneo para seguir "el estudio de un proyecto" (ver anexo 2) abordando luego una variedad de programas arquitectónicos (habitaciones, prisiones, cuarteles y puertas de ciudades), considerados "todos estos edificios, objeto de un análisis claro, instructivo, y que probablemente construirán más tarde los alumnos egresados de la institución" (Dartein, 1874 , p. 8). Tal y como era la intención de las escuelas de aplicación, las últimas lecciones del Traité d'architecture introducían al alumno a la concepción de "vías de comunicación" (carreteras, vías férreas, vías navegables, ouvrages d'art). La comparación entre las notas de clase tomadas el un curso de Reynaud en el año 1850-1851, y posteriormente aquellas tomadas en un curso de Dartein en el año 1874-187520, muestra que dicho esquema conoció solamente algunas evoluciones menores, iniciadas por Reynaud o inscritas en los contenidos de su Traité d'architecture. La primera evolución tuvo que ver con la importancia creciente atribuida a la construcción metálica (una sola lección en 1851, cuatro lecciones en 1875), mientras que una segunda evolución obedeció a la inflexión histórica que se reconoce en el curso de Dartein, en lo que concierne a las lecciones sobre salas abovedadas y planas. Los ejemplos de iglesias y de basílicas se convirtieron en el soporte de una "digresión arqueológica" que presentaba "a grandes rasgos los diversos estilos arquitectónicos en uso" (Dartein, 1874, pp. 8-9). Este desplazamiento hacia la historia de la arquitectura se acentuó aún más hacia finales del siglo.

20 Ver las notas conservadas en los archivos de la École (AEP, III, 3, e, núm. 1) de los alumnos François Xavier Kretz (curso de Reynaud, 1851-1852), y Gustave Louis (curso de Dartein, 1874-1875).

\section{Las modalidades de la transmisión: toma de notas y ejercicios gráficos}

Así como la cantidad y el contenido de las clases permanecieron estables para el periodo 18501875, las modalidades pedagógicas también corrieron igual suerte. La reforma de 1850 codificó un modelo de transmisión estrictamente definido en los programas. La clase magistral, de una duración de aproximadamente una hora y cuarto, era impartida a toda la promoción (150 alumnos en 1870) en el auditorio. Los estudiantes redibujaban sobre hojas dobles, suministradas y estampilladas por la misma École Polytechnique, las figuras trazadas en el tablero por el profesor, acompañándolas de algunas notas. De acuerdo con un procedimiento practicado igualmente en los cursos de geometría y de estereotomía, las notas tomadas allí eran complementadas bajo la dirección del répétiteur durante un examen posterior a la clase (Figuras 6 y 7), y constituían el cuaderno del alumno, que luego era corregido y calificado.

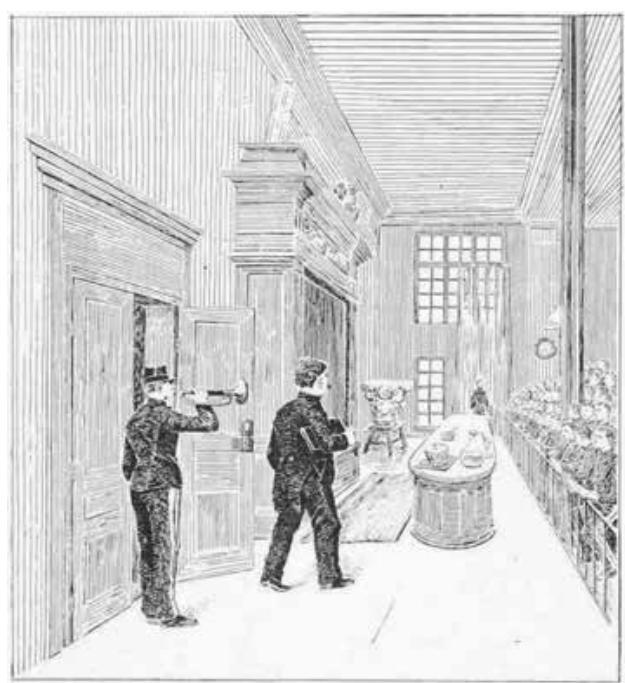

(A) Figura 6. El auditorio, con un modelo en yeso de un capitel

Fuente: Claris (1895, p. 26)
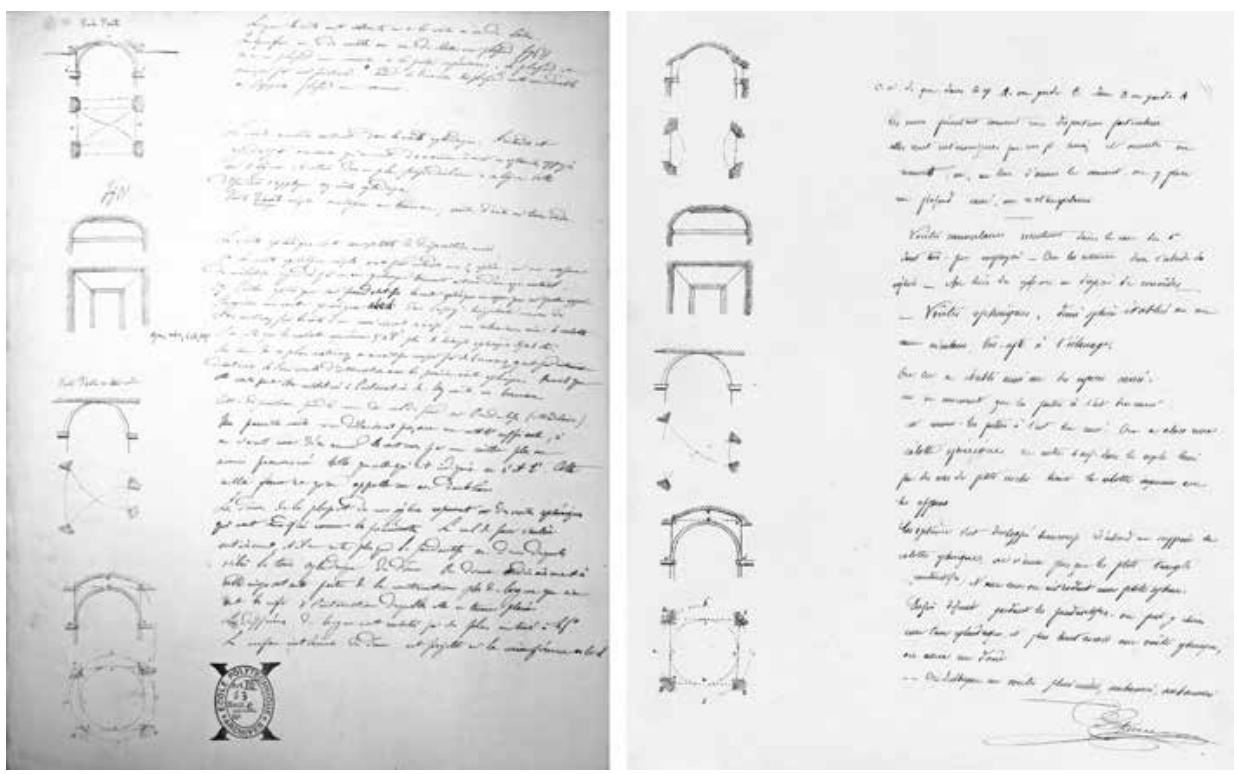

A Figuras 8 y 9. "Bóvedas": similitudes entre las notas tomadas en el curso de Léonce Reynaud durante el año 1851 por el alumno François Xavier Kretz (a la izquierda), y en el curso de Fernand de Dartein durante el año 1881 por el alumno Etienne Charles (a la derecha)

Fuentes: Archivos de la École Polytechnique (AEP), y colección particular. 


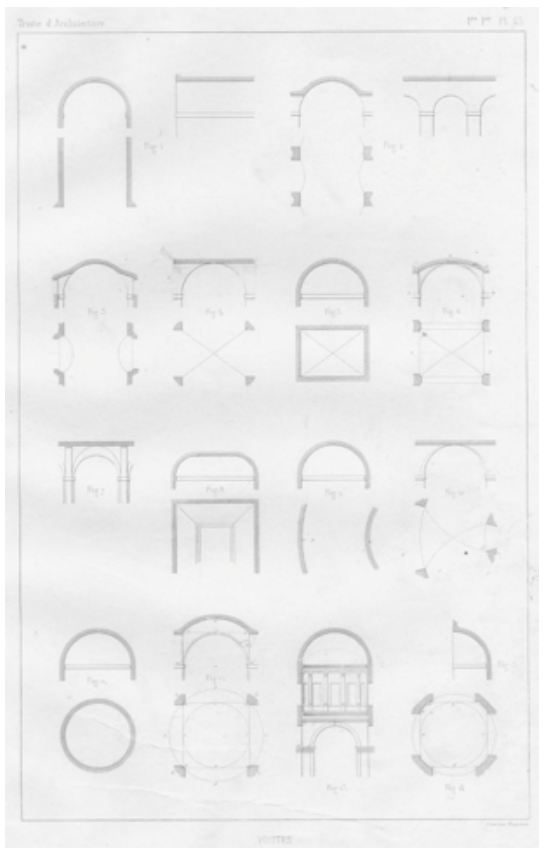

A Figura 10. Lámina sobre "Bóvedas", que servía como referencia en el curso de Dartein

Fuente: Reynaud (1850-58, $1^{\circ}$ partie, p. 43$)$.

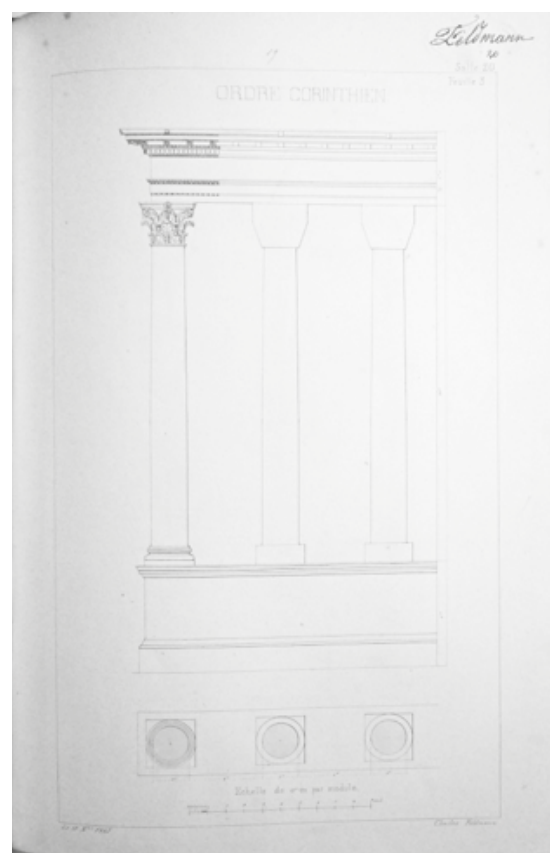

(A) Figura 11. "Orden corintio"

Fuente: Archivos de la École Polytechnique (AEP).

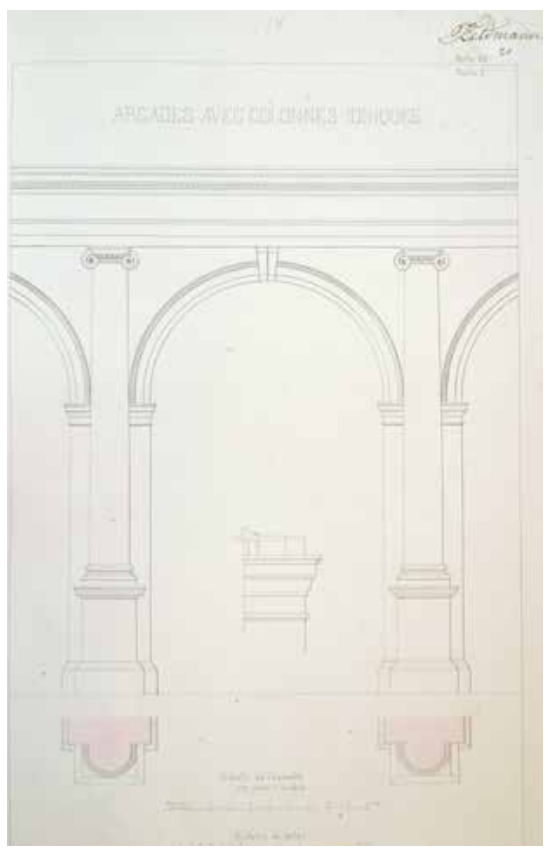

(A) Figura 12. "Arcos con columnas jónicas", alumno Charles Feldmann, octubre de 1867 y enero de 1868

Fuente: Archivos de la École Polytechnique (AEP).
Los dibujos consignados en las márgenes de estos muestran similitudes con las figuras del Traité d'architecture reproducidas a menudo fielmente. Originado en la labor docente, el Traité constituyó el principal referente del curso de arquitectura: el programa del curso es trazado a partir del plan de la publicación, valiéndose para ello de las figuras y los modelos impresos, máxime si se tiene en cuenta que un portafolio con veinte láminas tomadas del libro de Reynaud era suministrado al alumno como referencia ${ }^{21}$. Las semejanzas constatadas en los cuadernos de alumnos del curso de arquitectura entre 1850 y 1880 (Figuras 8, 9 y 10) resultan obvias a pesar del cambio de profesor.

Las notas a mano alzada tomadas habitualmente durante el curso de arquitectura constituyeron un entrenamiento gráfico que sería reemplazado más tarde por una serie de ejercicios más consecuentes ejecutados en los salones de examen, con los instrumentos necesarios y la asistencia del répétiteur ${ }^{22}$. Hasta 1870, los alumnos realizaban anualmente una serie de bocetos ${ }^{23}$ que incluían: órdenes dórico, jónico y corintio (Figura 11), arcos

21 El portafolio de láminas asociado al curso de Dartein es idéntico al distribuido en su momento por Reynaud. Hay que señalar que las láminas del Traité d'architecture utilizadas también como láminas en el portafolio, incluían casi todas las correspondientes al uso de la piedra, e ilustraban los "elementos" y las "combinaciones". Solamente dos estaban consagradas a la madera, ninguna al metal.

22 Emmanuel Brune fue répétiteur entre 1876 y 1881; Auguste Choisy, entre 1881 y 1901; y Umbdenstock lo fue entre 1901 y 1910.

23 Según la descripción presente al final del cahier de Gustave Louis, ocho diseños en total fueron ejecutados entre 18741875: órdenes dórico, jónico y corintio, arcos sobre piédroits, arcos con columnas jónicas, ventanas, sala plana y proyecto para un ayuntamiento. El número de diseños consignados fue disminuyendo progresivamente. sobre piédroits, arcos con columnas jónicas (Figura 12), ventanas y sala plana; bocetos todos que sustentan las semejanzas encontradas con el Traité de Reynaud, más aun por cuanto se les proponía redibujar láminas del portafolio: el último de tales bocetos consistía en la reproducción a escala de algún proyecto de edificio público, completándolo y retocándolo en aguada.

Con veinticinco años de diferencia, los trabajos presentados por los alumnos seguían repitiendo a partir de un mismo plano y de un mismo corte, propuestas arquitectónicas variadas para un mismo proyecto de "biblioteca" (Figuras 13 y 14); ya hacia finales de siglo, el ejercicio se aplicó para un "ayuntamiento" (Figuras 15 y 16).

Un tercer tipo de ejercicio se sumaba a la toma de notas y a la realización de dibujos: para el final del ciclo de clases los alumnos efectuaban, sin la ayuda de los répétiteurs, un total de cuatro proyectos de composición arquitectónica en el marco de actividades denominadas "concursos", que evocaban claramente los ejercicios practicados en la École des Beaux-Arts de Paris. A diferencia de los ejercicios desarrollados en los cursos, los temas propuestos en tales "concursos" variaban anualmente: para el año 1867-1868 fueron propuestas, por ejemplo, una oficina de recaudación (Figura 17), una estación ferroviaria (Figura 18), una aduana (Figura 19) y una orangerie (Figura 20). El enunciado del "concurso" estipulaba un programa arquitectónico senciIlo con superficies cuantificadas para ser desarrollado en un terreno rectangular establecido: el proyecto debía ser concebido y entregado -incluyendo planta, corte y alzado en aguadasobre una cuadrícula previamente impresa para simplificar la aplicación de la escala. 


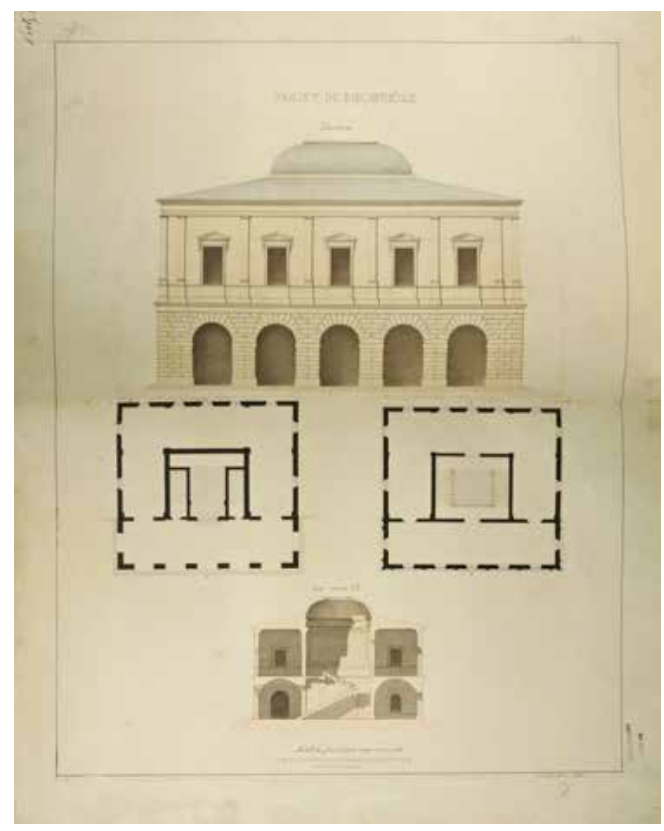

(A) Figura 13. "Biblioteca", proyecto del alumno François Xavier Kretz, mayo de 1852

Fuente: Archivos de la École Polytechnique (AEP).

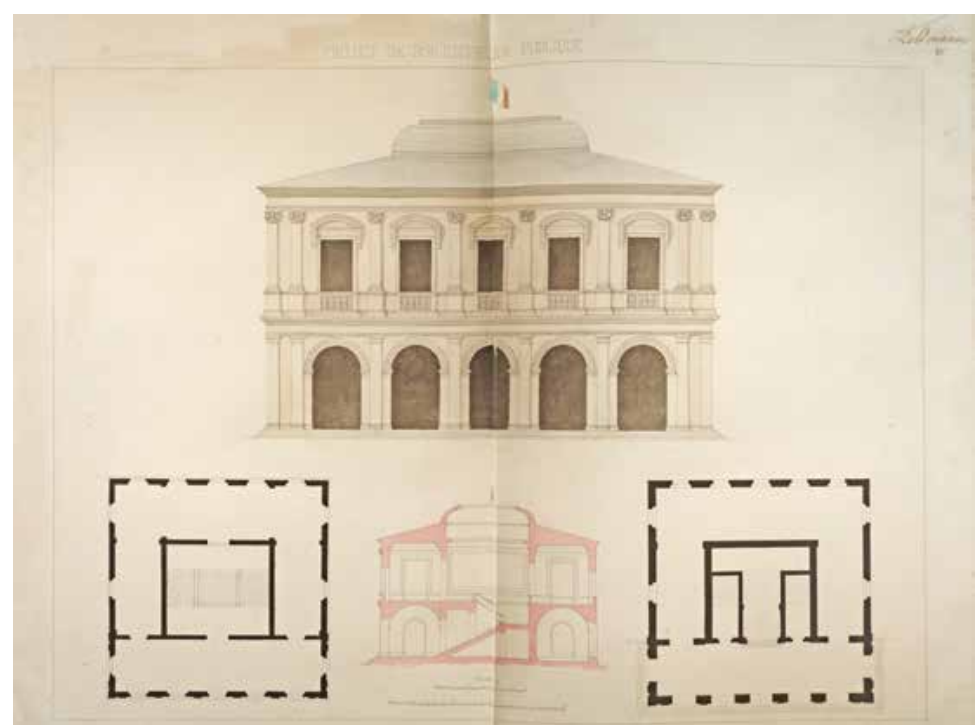

(A) Figura 14. "Biblioteca", proyecto del alumno Charles Feldmann, 1868 Fuente: Archivos de la École Polytechnique (AEP).

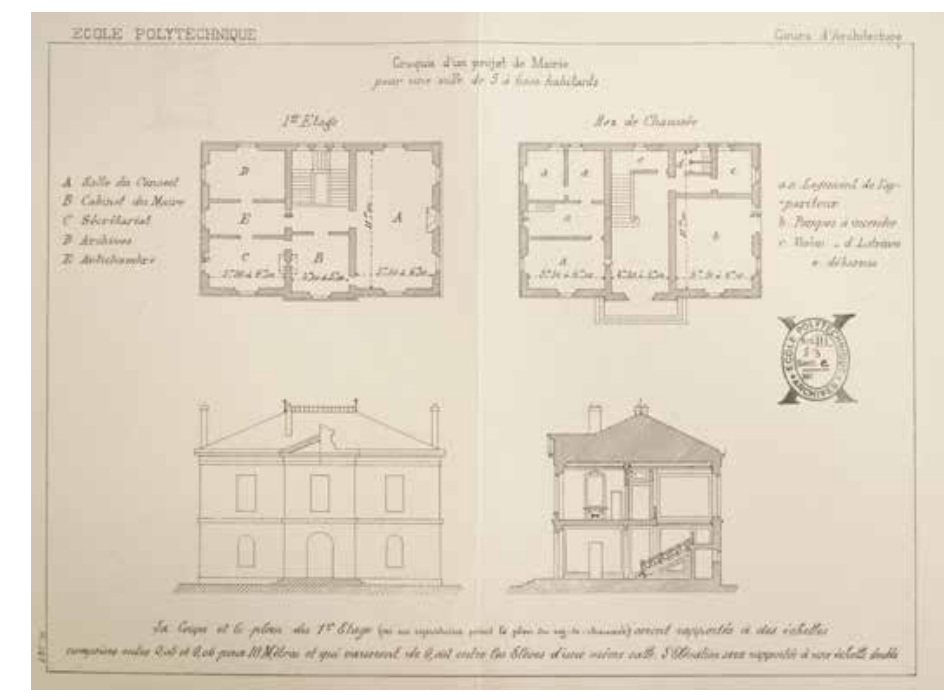

(A) Figura 15. Documento entregado a los alumnos para realizar el ejercicio sobre un "Ayuntamiento", sin fecha (finales del siglo XIX) Fuente: Archivos de la École Polytechnique (AEP).

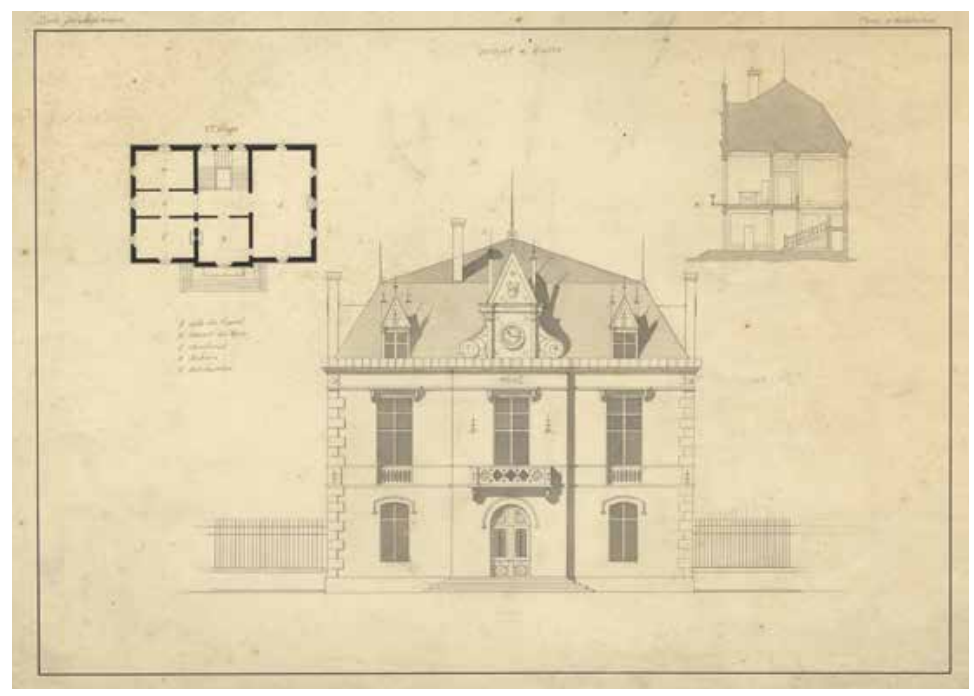

(A) Figura 16. Ayuntamiento, proyecto de estudiante, sin fecha (finales del siglo XIX)

Fuente: Colección particular.

\section{La iniciación a una arquitectura progresivamente simplificada, 1875-1906}

En 1874, el conjunto de trabajos gráficos que según Dartein servían para ejercitar y evaluar la aptitud del alumno en el ámbito de la composición arquitectónica, ocupaba un total de 132 horas del tiempo anual de estudio, aparte de las cincuenta horas correspondientes a las clases magistrales (Dartein, 1874, p. 6). El método pedagógico y la coordinación entre asignaturas ansiaban, por así decirlo, la productividad de aquellas cinco horas semanales destinadas en exclusiva a la arquitectura.

En el último tercio del siglo XIX se aceleró el declive de las disciplinas gráficas, abriendo paso a un plan de estudios de corte politécnico, progresivamente orientado hacia las ciencias aplicadas, lo cual obligaba a concentrar el contenido y las prácticas en tiempos cada vez más reducidos.
En el caso de la arquitectura, la disminución gradual del número de clases (cuarenta en 1875, treinta y seis en 1881, treinta en 1903) se vio acompañada de la reducción de ejercicios gráficos. Los críticos señalaban el lugar destacado ocupado por la construcción en el curso de Dartein, argumento invocado recurrentemente para buscar reducir la intensidad horaria de los cursos sin por ello renunciar al rol de iniciación artística atribuido a la arquitectura por los propios fundadores de la École Polytechnique ${ }^{24}$. Dartein fue obligado a ajustar la estructura de las clases, aunque pudo defender su visión con respecto al enfoque técnico.

24 La reducción a treinta lecciones propuesta en 1903 fue interpretada por Dartein como el resultado de "una poda progresiva a la obra de la comisión de 1850" que había anteriormente concedido importancia a los cursos de arquitectura sin menospreciar la relevancia de la dimensión constructiva (Dartein, 1874, p. 6). 

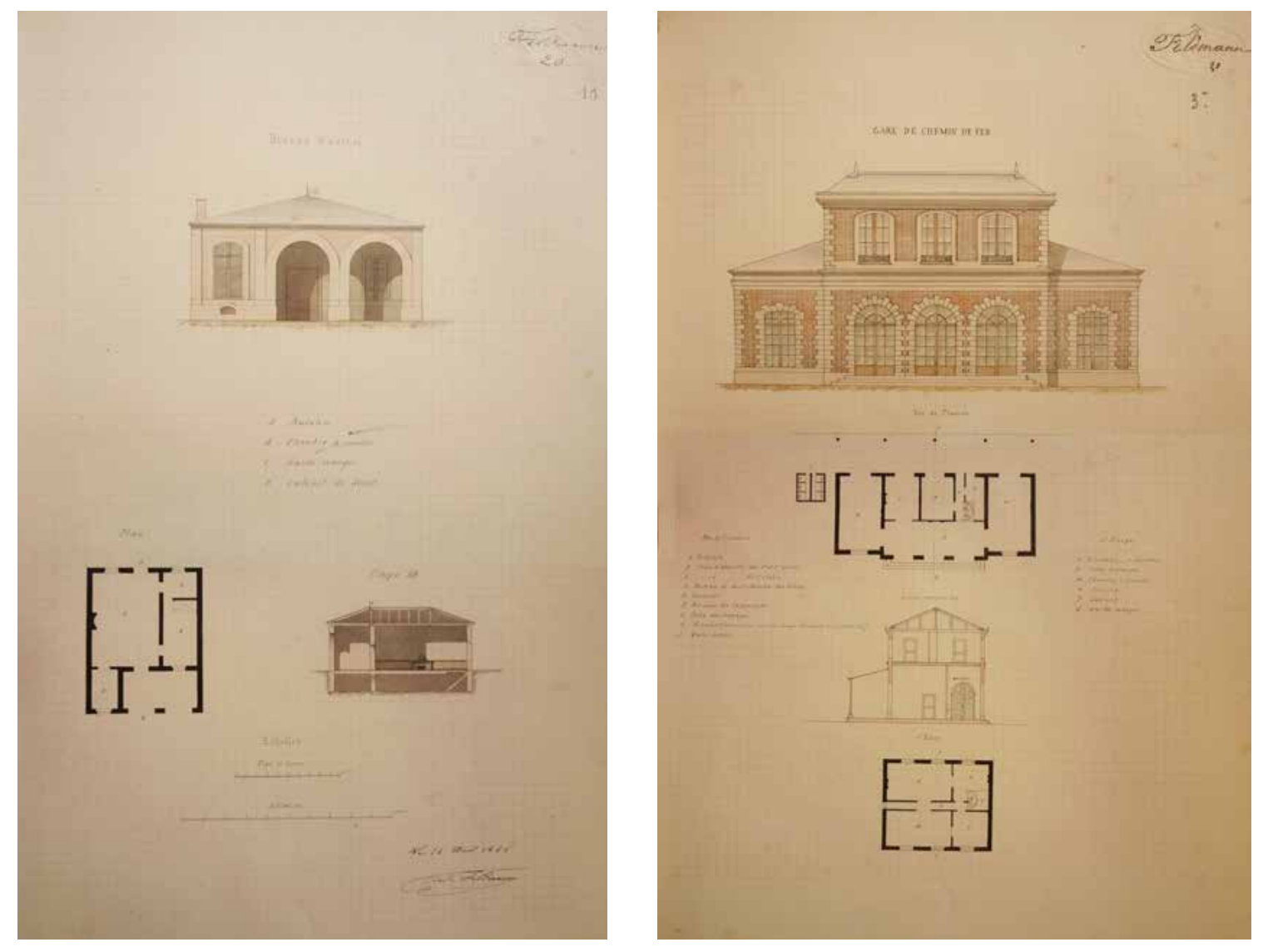

De acuerdo con las notas tomadas por los

A) Figura 17. "Oficina de recaudación"

(4) (A) Figura 18. "Estación

ferroviaria". Proyectos

para concursos de la École

Polytechnique, trabajos del alumno Charles Feldmann, 1868

Fuente: Archivos de la École Polytechnique (AEP) dio de los materiales continuó siendo la hipótesis alumnos, el curso no fue recortado sino más bien condensado, y la interacción entre construcción y composición arquitectónica a partir del estufundamental que guiaba el desarrollo del curso. Se constata de esta forma la concentración de un mismo contenido, aunque se presentaron algunas inflexiones particularmente en beneficio de la historia de la arquitectura. A partir de 1874, Dartein reforzó "la cuota de la arqueología" al introducir "cuatro lecciones en las cuales pasaba revista y estudiaba en su carácter esencial, los sucesivos estilos arquitectónicos desde la época romana hasta nuestros días" (Dartein, 1874, p. 7). La importancia concedida a la historia encontró un soporte en las recopilaciones de fotografías que el docente puso a disposición de los alumnos y que constituyen los once volúmenes del Recueil de vues photographiques de monuments d'architecture. La iniciación artística asumida por la arquitectura se volcó poco a poco hacia el conocimiento histórico a medida que disminuía la cuota correspondiente a los ejercicios gráficos.

El lugar ocupado por la arquitectura era discutido, ya no de forma aislada, sino además frente a las otras disciplinas relacionadas con el dibujo, desde el enfoque de una economía de escala más general: así, la posición de la geometría descriptiva, de la arquitectura, del diseño de máquinas y del dibujo de imitación pasaron a ser debatidas de manera conjunta. A partir de 1881, la distribución en dos años de las treinta clases de arquitectura y de los respectivos ejercicios asociados, se inscribió en una gestión global del número de bocetos que debían ser efectuados en las diferentes asignaturas. Mientras que las aguadas sombreadas de capiteles - practicadas desde Durand- eran suprimidas, los bocetos de los tres órdenes arquitectónicos -que habían sido cambiados para el primer año- se convirtieron en sus sustitutos. El curso de arquitectura concentró los contenidos establecidos por Reynaud, y el trabajo gráfico mantuvo hasta los primeros años del siglo XX una síntesis de prácticas instauradas a mediados del siglo XIX; todo ello mientras se institucionalizaban, por así decirlo, los tres componentes fundamentales del curso: la entrega de apuntes, los dibujos y los concursos. De esto da fe una nota de Gustave Umbdenstock fechada en 1906, en la que describe su trabajo como répétiteur ${ }^{25}$. Umbdenstock era el encargado de corregir las notas correspondientes a las treinta lecciones de las dos promociones: cuatro dibujos en el primer año (un estudio comparado de los tres órdenes y un tramo de órdenes superpuestos) y dos en el segundo año (el análisis en aguada de un detalle y el proyecto para un ayuntamiento), y dejaba al profesor titular el privilegio de evaluar los tres concursos (en 1906 se trató de "un pabellón de habitación en un parque", "una pequeña estación de tren" y "un pabellón de caza"). Esta constancia, tanto en las clases como en los ejercicios demuestra sin duda la resistencia de unas prácticas pedagógicas tradicionales en detrimento de la evolución del perfil de formación del ingeniero. La estabilidad de la enseñanza de la arquitectura

25 Ver la Lettre à M. le Directeur des études de l'École Polytechnique (1901). 

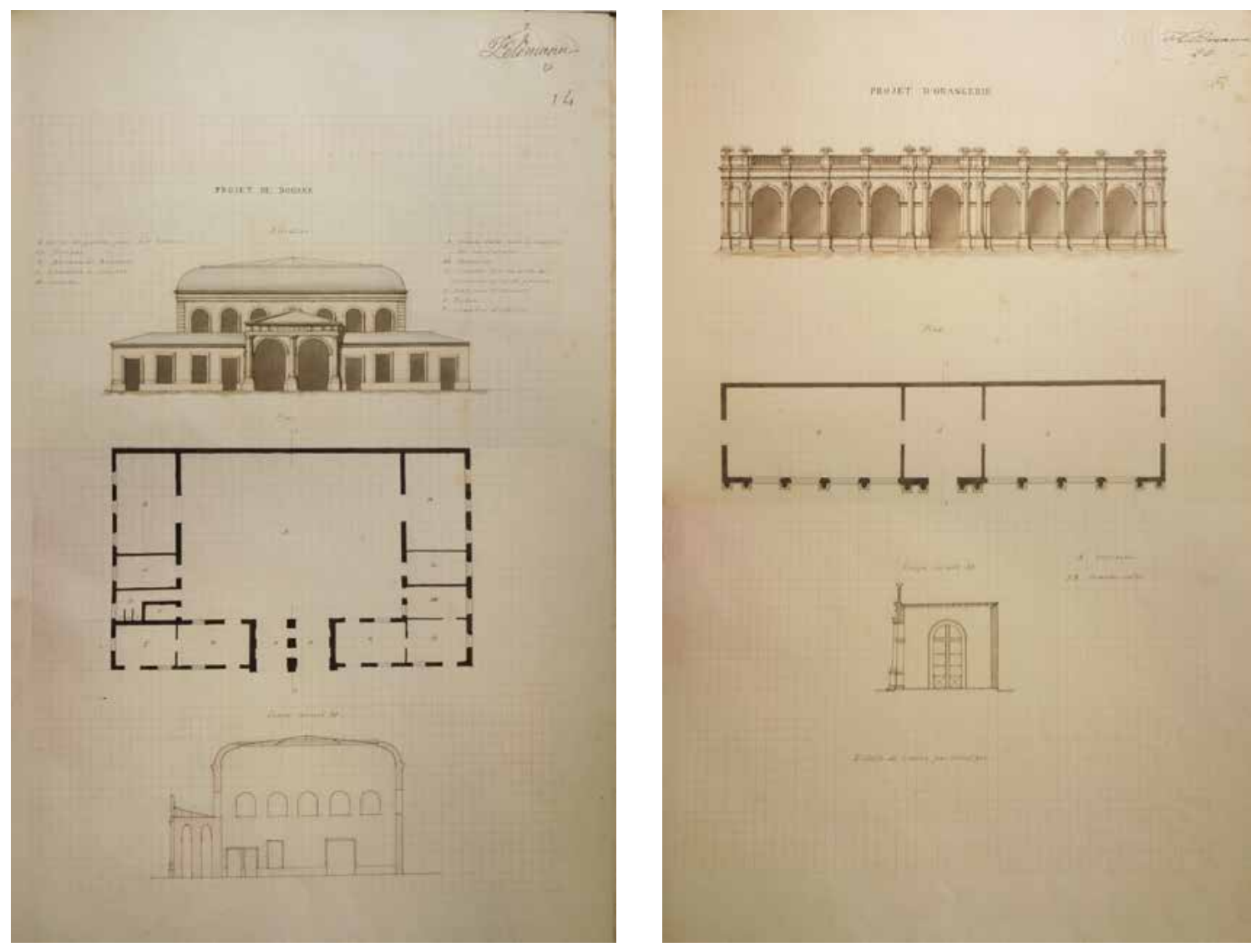

contrastaba en ese sentido con las modificaciones mucho más dinámicas que se dieron en la enseñanza del dibujo "artístico", especialmente cuando Eugène Guillaume (1822-1905) fue nombrado profesor de dibujo ${ }^{26}$ en 1887. Cabe recordar que Guillaume fue el artífice en los años 1870-1880 de una ambiciosa reforma nacional en la enseñanza escolar del dibujo, que puso en orden la totalidad del plan de estudios para los alumnos de las escuelas primaria y secundaria ${ }^{27}$.

El objetivo de dicha reforma estuvo enfocado en atenuar la ruptura entre arte e industria con el fin de mejorar la calidad de aquello que se producía, considerando al dibujo como una lengua común entre obreros, artistas, artesanos e industriales. Ahora bien, los cambios introducidos por Guillaume en la École Polytechnique pueden verse como la última fase de un plan de estudios completo que se proyectaba desde la escuela elemental hasta la formación para los ingenieros, propugnando el acercamiento entre el enfoque científico y el enfoque artístico del dibujo. Guillaume dejó de lado el uso de las antiguas copias de láminas litografiadas, para privilegiar la práctica del croquis realizado con base en la observación de modelos reales de partes ana-

26 Después del profesorado de Léon Coignet, entre 1846 y 1861, la enseñanza del dibujo fue confiada únicamente a maestros del oficio, hasta la nominación de Adolphe Yvon en 1881. Eugène Guillaume lo sucedió entre 1887 y 1894 . En la misma línea de las orientaciones de Guillaume, Lucien Doucet, y más tarde Paul Alfred Colin, ocuparon esta plaza entre 1895 y 1896, y entre 1896 y 1918, respectivamente.

27 Ver Un art pour tous. Le dessin à l'école de 1800 à nos jours (2004) tómicas, o de fragmentos de arquitectura a partir de modelos en yeso o in situ -directamente en el patio de la escuela-. En los años siguientes, los debates sobre el dibujo valorizaron la formación del alumno en la realización del croquis documental, "auxiliar inmediato de los cursos científicos", al tiempo que se le exigía a la práctica del dibujo su participación en toda formación artística $^{28}$. ¿En qué medida pudo esta modernización de la enseñanza del dibujo contribuir al desprestigio de los métodos heredados de Reynaud? En tal sentido, particularmente los ejercicios de copia de láminas de portafolios pudieron en efecto parecer obsoletos en un momento en el cual el profesor de dibujo prefería ya conducir a sus alumnos a espacios al aire libre para dibujar directamente edificios situados en el exterior de las aulas.

\section{De los cursos a las conferencias, 1907-1913}

\section{La supresión anunciada del curso de arquitectura}

Al comenzar el siglo XX, la arquitectura fue descrita cada vez más a menudo como una disciplina marginal, secundaria, cuyo rol fue el de introducir una compensación artística y cultural en un plan de estudios donde dominaban las

28 Sobre este tema resultan fundamentales los elementos consignados en "Renseignements sur I'enseignement du des$\sin ^{\prime \prime}(1897-1904)$. Por otro lado, la cuestión sobre la enseñanza de la fotografía también fue planteada: ver la nota relativa a la "creación práctica de un curso de fotografía" (1909).
(A) Figura 19. "Aduana" (A) Aigura 20. Orangerie. Proyectos para concursos de la École Polytechnique, trabajos del alumno Charles Feldmann, 1868

Fuente: Archivos de la École Polytechnique (AEP). 
directrices científicas. En 1907, un boletín sobre los programas prefiguraba el desmantelamiento del curso de arquitectura ${ }^{29}$ denunciando su carácter demasiado "utilitario", más apropiado para las escuelas de aplicación; el boletín proponía la supresión de las asignaturas de construcción y programas de edificios, para así conservar únicamente aquellas que abordaban verdaderamente la dimensión artística de la arquitectura, en otras palabras, las asignaturas que trataban el tema de los órdenes y los estilos. De esta manera, de las treinta sesiones del curso de arquitectura solamente ocho fueron juzgadas como dignas de ser conservadas $^{30}$. En el boletín se subrayaba el hecho de no poder atribuir la denominación de "curso" cuando se trataba -como en este casode un reducido número de clases, y se proponía por ello reemplazarlo con simples "conferencias" que no dieran lugar a otros ejercicios diferentes a la toma de notas de clase. Por otro lado, la utilización de proyecciones en sustitución del dibujo en el tablero permitiría una percepción más amplia; un curso litografiado sería entregado al alumno como referencia, y se organizaría una serie de visitas a monumentos y museos como extensión de las conferencias. En cuanto a las "aplicaciones" de estas lecciones, se estimaba que podían ser movilizadas hacia ejercicios gráficos desarrollados en el marco del curso de dibujo.

En los años siguientes, la revisión de los programas -orquestada por un nuevo director de estudios- llevó a la escuela hacia una reforma aún más radical: en julio de 1908, en un comunicado de la inspección permanente de las escuelas militares se solicitaba la supresión total del curso de arquitectura, aunque se proponía mantenerlo hasta la jubilación de Dartein que tendría lugar en 1910 (général Joffre, 1908), mientras que los ejercicios gráficos en cambio fueron suprimidos de forma inmediata. El comunicado afirmaba: "el curso de arquitectura no parece tener un lugar en la formación dispensada en la École Polytechnique", esto, en la medida en que los rudimentos sobre la construcción que el curso proveía eran retomados luego en asignaturas más avanzadas; y además, en vista de la supuesta ineficacia del curso para proporcionar nociones "de arqueología y de arte", se sugería que "si es posible despertar la curiosidad de los alumnos sobre cuestiones de estética, parece más adecuado que esto se dé en el marco de conferencias de formación general, por fuera de los cursos normales" ${ }^{\prime \prime}$.

29 Ver la "Note sur la nécessité de réviser les programmes" (1907).

30 Tres sesiones sobre los órdenes, y otras cinco sobre la historia de los estilos en las cuales se abordaron específicamente temas como: los espacios abovedados y cubiertos de la arquitectura romana, las primeras basílicas cristianas, la arquitectura romano-bizantina y la arquitectura del medioevo.

31 "Comme celles que vous aviez demandé I'autorisation d'organiser dès cette année par votre lettre du 27 février 1908" (Dartein, 1874); el comunicado evoca sin duda
Esta solicitud de supresión suscitó diversas reacciones, comenzando por la del propio Dartein, quien elaboró en octubre de 1908 un folleto análogo al que ya había redactado en 1874 para defender el rol de su disciplina (Dartein, 1908), argumentando de nuevo esta vez la necesidad del curso de arquitectura y de los ejercicios gráficos en coherencia con los principios fundadores de la École Polytechnique. Dartein propuso, sin embargo, una pésima solución para conservar la arquitectura en un contexto de horarios sobrecargados: reducir el periodo de vacaciones, y argumentó, además, que la arquitectura debía constituir para el ingeniero, un entretenimiento mucho más fructífero que la inacción... La École des Ponts et Chaussées por su parte, apoyó decididamente a Dartein en su protesta en contra de la supresión de un curso que consideraban absolutamente necesario para la formación de sus futuros alumnos, tal y como se constata en el documento titulado "Observations tendant au maintien du cours d'architecture à Polytechnique", redactado en $1909^{32}$ por Arthur Bonnet y Paul Séjourné.

Asimismo, en la École Polytechnique, otras voces se elevaron para defender la arquitectura, integrando a esta protesta otras críticas generalizadas con respecto al sistema pedagógico existente. El boletín titulado École Polytechnique. Modifications proposées pour l'enseignement intérieur, emitido en septiembre de 1908 por iniciativa del ingeniero y arquitecto Jules Pillet (1842$1912)^{33}$, resulta esclarecedor por cuanto el autor se basó fundamentalmente en su propia experiencia como antiguo estudiante de Reynaud, y en el análisis de ciertas prácticas didácticas que había experimentado en otras instituciones. Profesor de dibujo de máquinas en la École Polytechnique desde 1874, Pillet desarrolló su actividad como docente en numerosas instituciones: en la École des Ponts et Chaussées desde 1867 y en la École Spéciale d'Architecture desde 1878; enseñó descriptiva en la École des Beaux-Arts desde 1883, e incluso reemplazó en 1894 a Émile Trélat (1821-1907) en la cátedra de construcciones civiles en el Centre National des Arts et Métiers. Como inspector de dibujo entre 1878 y 1894, participó activamente en la reforma a la educación del dibujo emprendida por Eugène Guillaume. Pillet se oponía a la reducción del curso de arquitectura a simples

las conferencias organizadas a partir de 1908 por Gustave Umbdenstock.

32 Sobre este aspecto, ver también la carta fechada el 27 noviembre 1909, del director de la École des Ponts et Chaussées al ministro de Travaux publics, en la cual se aboga por la permanencia del curso, por cuanto la supresión del mismo implicaría la inmediata creación de una asignatura equivalente en la École des Ponts et Chaussées.

33 Sobre Jules Pillet, ver los dos textos de Frédéric Seitz: "Jules Pillet (1842-1912), professeur de Constructions civiles (18941912)" (1994), y "L'Enseignement de la construction, de l'architecture et du dessin à la fin du xixe siècle et au début du xxe siècle, l'apport d'Émile Trélat et de Jules Pillet" (1993). 
conferencias sobre historia de los estilos, apoyándose en la defensa de la especificidad de una enseñanza que debía formar especialistas y no simplemente "amateurs ilustrados"; Pillet preconizó la preservación de un curso de arquitectura orientado hacia el aprendizaje de la concepción arquitectónica y acompañado de ejercicios gráficos, aunque sugirió, por otro lado, una revisión completa de los métodos de transmisión para ajustarlos a una intensidad horaria reducida. Por esto, la toma de apuntes durante la clase magistral era fuertemente criticada ya que se efectuaba en detrimento de la realización de croquis. Pillet propuso revertir el esfuerzo del alumno en beneficio del dibujo, suministrándole un documento impreso (autographié) al cual podría remitirse por fuera del tiempo de la clase: distribuir un documento escrito que recogiera todas las nociones elementales economizaría el tiempo de discurso del profesor, quien no tendría ya la necesidad de exponer oralmente la totalidad del contenido. En definitiva, el tiempo de la clase podía así ser empleado en el ejercicio de competencias gráficas. Como alternativa a los bocetos de las láminas provenientes de los portafolios impresos, copiados una y otra vez de manera "estéril", Pillet sugirió utilizar las sesiones llevadas a cabo en el anfiteatro para dibujar sobre un modelo geometral más detallado los ejemplos arquitectónicos representados en grandes lienzos de más de dos metros de alto. El alumno tendría que ejecutar un solo dibujo por sesión, mientras que el profesor construiría su exposición a partir de la explicación consagrada al edificio en cuestión. La clase se convertiría así en una especie de estudio de caso, pretexto para el ejercicio gráfico. Pillet manifestó igualmente su convicción de la necesidad de una práctica de "interrogantes dibujados" sobre temas arquitectónicos, insistiendo en el hecho de que los modelos propuestos se apoyaran en experiencias pedagógicas practicadas igualmente en otras instituciones en donde él estaba implicado: así, establecimientos de enseñanza como el Centre National des Arts et Métiers o la École Spéciale d'Architecture, podrían haber servido entonces como recurso para la reflexión sobre la eficacia didáctica en el seno de la École Polytechnique. Dartein invocaba, por otro lado, algunas continuidades con la École des Ponts et Chaussées, y el ejemplo del curso creado por Fernand Delmas (1852-1933) en la École Centrale des Arts et Manufactures, para así legitimar el programa y la estructura de sus propias lecciones (Dartein, 1908, p. 21).

Como muestra de la voluntad de reformar el curso de arquitectura en vez de suprimirlo, los archivos guardan el sumario de un curso elaborado en 1909 y enviado a la dirección; el autor probablemente Gustave Umbdenstock, enumeraba los temas "susceptibles de ser estudiados, ya sea en la École Polytechnique, o bien en las escuelas de aplicación" ${ }^{34}$ (Umbdestock, 1913).

Dicho programa desplazaba los contenidos del curso de arquitectura hacia cuestiones de expresión y de composición arquitectónica, sugiriendo nuevas orientaciones que podían asimismo inspirarse en prácticas de otras instituciones con formaciones en arquitectura: el uso de las "proyecciones Molteni", la visita a monumentos, la elaboración de dibujos en perspectiva o de pequeñas maquetas.

Todas estas propuestas evidencian cómo la amenaza de supresión del curso obligó a argumentar una vez más la pertinencia de la arquitectura para la formación del ingeniero, justo cuando la pronta partida de Dartein abría una posibilidad para actualizar los métodos de enseñanza. Esta coyuntura motivó debates sobre la eficacia pedagógica ante la redistribución de horarios de los alumnos, invitó a informarse en cuanto a las prácticas didácticas contemporáneas, motivó a interrogarse sobre los roles de lo oral, de lo escrito y lo gráfico en la enseñanza de la arquitectura, y promovió la reflexión en torno al papel de los intercambios y las transferencias entre disciplinas.

\section{Las conferencias de arquitectura: ideclive o renovación de la enseñanza?}

Los dos últimos años de docencia de Dartein, entre 1908 y 1910, fueron años de transición: al sentirse perjudicado por lo que consideraba como una afrenta personal, Dartein se preparó para jubilarse a medida que Gustave Umbdenstock, su répétiteur, fuera asumiendo el nuevo rol. Desde 1908, Umbdenstock anticipó las futuras transformaciones: paralelamente a las últimas clases impartidas por su superior, dicta entonces algunas "conferencias de arquitectura" por fuera del plan de estudios, pero seguidas con entusiasmo por los estudiantes ${ }^{35}$. Los textos y los dibujos incluidos en Ombres, una publicación anual de la institución que reunía caricaturas hechas por los propios alumnos, recrean el contraste entre "Dart" (Dartein) cuya monotonía "arrulladora" podía adormecer rápidamente al auditorio, y Umbdenstock, mejor conocido como el "InfraDart", quien era descrito en cambio como alguien especialmente dinámico ${ }^{36}$ (Figuras 21 y 22).

34 "Al Sr. General Kreitmann, comandante de la École Polytechnique. Sumario de un curso de arquitectura. Lista de programas susceptibles de ser estudiados en la École Polytechnique, o en las escuelas de aplicación" (3 p. AEP, III. 3. E). El documento no está firmado pero las orientaciones propuestas permiten pensar que el autor es Umbdenstock, más aún por cuanto él afirma en una carta fechada en 1913, que había redactado un programa así en 1909.

35 Ver especialmente las tres conferencias tituladas: Conférence d'architecture (1908); La porte à travers les âges (texto autographié, con croquis en las márgenes); y Du dessin et du lavis d'architecture (texto dactilografiado).

36 Ombres, 1909 (AEP, X2B31). 
tectura fue desde entonces vista como una materia anexa y relacionada con la cultura general, del mismo modo que podía estarlo la literatura. Con pleno compromiso, Umbdenstock realizó sus conferencias integrando perfectamente en ellas las sugerencias que emanaban de la dirección de estudios de la École Polytechnique, como sucedió específicamente cuando prescindió de las cuestiones netamente constructivas para situar en un primer plano las cuestiones estéticas. Así por ejemplo, las construcciones en madera y en hierro (ver anexo 3) fueron abordadas solo desde la perspectiva de su "valor expresivo", mutación de contenidos que se vio acompañada de un cambio de estilo. Las doce conferencias dictadas por fuera del plan de estudios adquirieron inmediatamente un estatus que podría calificarse casi de entretención, con Umbdenstock como gran orador, el cual aseguraba un verdadero espectáculo. Al escucharlo, el auditorio se entusiasmaba tanto por el uso de una retórica apoyada en una serie de metáforas científicas que evocaba un imaginario prestado de otras formaciones -mecánica, física, química...-, como por la expresión de un agresivo discurso patriótico que situaba la estética arquitectónica como un asunto de compromiso nacional. Umbdenstock aparece descrito en las historias consagradas a la École Polytechnique como un "coloso rugiente", apreciado particularmente por los alumnos, y que desencadenaba las pasiones en un auditorio que los capitaines de service se rehusaban a supervisar (Callot, 1982, p. 168). Y aunque los relatos expresados a través de las caricaturas publicadas en las páginas de Ombres resaltaban su excepcional talento verbal, Umbdenstock se esmeró igualmente en la organización y difusión de sus conferencias en un lenguaje escrito menos especializado, lo cual dio como resultado la publicación, en 1910, de las Douze conférences d'architecture.

Fue tal el éxito de aquellas conferencias, que en 1912 el Consejo de perfeccionamiento de la École solicitó a Umbdenstock reestructurar un curso de arquitectura de treinta lecciones, con lo cual se volvía en definitiva al escenario de 1909. Tal solicitud insistía, no obstante, en la necesidad de reformar los contenidos, para así "liberarse de la antigua influencia", es decir, de lo que representaba el legado de Reynaud ${ }^{40}$. En la víspera de la guerra, Umbdenstock redactó un programa que desarrollaba lo expuesto por él en las conferencias (ver anexo 4); este curso no sería puesto en marcha sino hasta después de terminada la conflagración. Alistado en el ejército de forma voluntaria en 1914, y herido en

40 Ver el informe titulado Architecture et dessin. Rapport du directeur des études (1912), así como los intercambios epistolares en 1913 entre el comandante la École Polytechnique (general Cornille) y el ministro de guerra de la época; y las cartas de Umbdenstock al director de estudios (M. Carvallo), al finalizar aquel mismo año.
1915, Umbdenstock fue condecorado por sus acciones militares, y nombrado a su regreso a la École Polytechnique en 1919 como profesor titular, cargo que conservará hasta su jubilación en 1937. Su personalidad y su admirable talento como orador parecen haber jugado un papel determinante para la supervivencia del curso de arquitectura, aun a costa de su transformación en un sistema de conferencias-espectáculo: su desempeño escénico aseguró a la enseñanza de la arquitectura un lugar de privilegio dentro de la formación de los ingenieros.

Desde Fernand de Dartein hasta Gustave Umbdenstock, el estudio de esta sucesión permite sobre todo evaluar la excepcional longevidad -durante siete décadas- del modelo pedagógico puesto en práctica por Léonce Reynaud, así como la importancia de su Traité d'architecture, referencia obligada en la enseñanza de la arquitectura hasta comienzos del siglo XX. Como evidente es también la continuidad de una definición sutil en los objetivos pedagógicos asignados a la arquitectura, situados en el cruce de caminos entre el saber técnico y constructivo, el dominio del dibujo y la adquisición de una cultura artística e histórica.

No obstante, la adaptación condensada de un modelo pedagógico apuntalado sobre los principios fundadores de la École resultaba, al comenzar el siglo XX, una respuesta insuficiente frente a las evoluciones que habían afectado hasta entonces el perfil de la formación del ingeniero. La transición gradual hacia Gustave Umbdenstock fue una buena ocasión para realizar ajustes más radicales que afectaban la definición misma de arquitectura: la desaparición de un arraigo técnico la empujaba hacia problemáticas estéticas, históricas y sociales. La enseñanza de la arquitectura en la École Polytechnique constituyó, en la época descrita, un espacio en el cual se acentuaban diferencias entre la arquitectura y la construcción, en otras palabras, entre un aprendizaje artístico de la composición arquitectónica integrado a un conocimiento histórico, y, por otra parte, la integración de la dimensión técnica. La marginalización de la disciplina que se hacía ya explícita con la transformación del curso de arquitectura en simples conferencias, era confirmada con la disminución progresiva de los ejercicios gráficos, lo cual se conectaba de manera global al menoscabo de la influencia de la geometría como asiento de la formación intelectual. La supresión de los "bocetos", utilizados inicialmente en la enseñanza de la geometría descriptiva, puso en evidencia la profunda transformación del estatus del dibujo, aun cuando la práctica de los croquis y de los "concursos", que se mantuvo hasta después de la Primera Guerra Mundial, pareciera revelar afinidades con las prácticas de la École des Beaux-Arts, preservadas durante largo tiempo. 


\section{Referencias}

Belhoste, B, Dahan-Dalmedico, A. y Picon, A. (dir). (1994). La formation polytechnicienne. Paris: Dunod.

Belhoste, B. (2002). Anatomie d'un concours. L'organisation de l'examen d'admission à l'École Polytechnique de la Révolution à nos jours. Histoire de l'éducation, 94, 141 175. Recuperado de https://www.cairn info/revue-histoire-de-l-education-20022-p-5.htm

Bonnet, A. y Sejourne, P. (1909). Observations tendant au maintien du cours d'architecture à Polytechnique, AEP, III, 3, e.

Callot, P. (1982). Histoire de l'École Polytechnique. Paris/ Limoges: Charles Lavauzelles.

Claris, G. (1895). Notre École Polytechnique. Paris: Librairies-Imprimeries Réunies.

D'Enfert, R. y Lagoutte, D. (2004). Un art pour tous. Le dessin à l'école de 1800 à nos jours. Lyon: INRP.

Dartein, F. de (s.d.a). Cours d'architecture, rédigé en 1909 par M. de Dartein, AEP.

Dartein, F. de (s.d.b). Recueil de vues photographiques de monuments d'architecture, once volúmenes. AEP, H2A79.

Dartein, F. de (1865). Étude sur l'architecture lombarde et sur les origines de l'architecture romano-byzantine. Paris: Dunod.

Dartein, F. de (1874). À Messieurs les membres du Conseil de perfectionnement. Observations sur le cours d'architecture de l'École Polytechnique et sur le programme de ses leçons. Paris: Imp. Simon Raçon.

Dartein, F. de (1885). Léonce Reynaud. Sa vie et ses œuvres par l'un de ses élèves. Paris: Dunod.

Dartein, F. de (1891-1893). Documents sur les fermes métalliques à grande ouverture, réu nis et coordonnés par F. de Dartein avec le concours de J. Boulard. Paris: Ministère des travaux publics, École Nationale des Ponts et Chaussées.

Dartein, F. de (1908). À Messieurs les membres du conseil de l'École Polytechnique. Observations tendant au maintien du cours $\mathrm{d}^{\prime}$ architecture dont la suppression ou la transformation en conférences est proposée par une dépêche du 17 juillet 1908 adressée par Monsieur le général inspecteur permanent des écoles militaires à monsieur le général commandant de l'École Polytechnique, Paris: Lahure, AEP, III, 3, a, núm. 1.

Dupont, J.-Y. (2000). Le cours de machines à l'École Polytechnique, de sa création jusqu'en 1850. Bulletin de la Société des amis de la bibliothèque de l'École Polytechnique, 25.

Général Joffre, Carta al Général Commandant de l'École Polytechnique, "Analyse: au sujet des programmes d'enseignement", Paris, 17 julio de 1908. AEP, III, 3, a, núm. 6.

Guigueno, V. Picon, A. (1996). Entre rationalisme et éclectisme, I'enseignement d'architecture de Léonce Reynaud. Bulletin de la société des amis de la Bibliothèque de l'École Polytechnique, 16, 12-21. Recuperado de https://journals.openedition.org/ sabix/800?lang $=$ en
Jaquet-Francillon, R., D'Enfert, R. y Loeffel, L. (2010). Une histoire de l'école. Anthologie de l'éducation et de l'enseignement en France $X V I I{ }^{e}-X X^{e}$ siècle, Paris: Retz. Recuperado de https://journals.openedition.org/ histoire-education/2474

Lucan, J. (2009). Composition non composition. Architecture et théories XIXe-XXe siècles. Lausanne: Presses Polytechniques et Universitaires Romandes.

Ministère de la Guerre (1861). Programmes de I'enseignement intérieur de l'École Impériale Polytechnique pour l'année 1860-1861. Paris: Imprimerie nationale, AEP.

Nègre, V. (2011a). L'enseignement de l'architecture au Conservatoire National des Arts et Métiers (1854-1971). En G. Lambert y E. Thibault (dirs.). L'atelier et I'amphithéâtre: les écoles de l'architecture, entre théorie et pratique. Wavre: Mardaga.

Nègre, V. (2011b). Architecture et construction dans les cours de l'École Centrale des Arts et Manufactures (1833-1864) et du Conservatoire National des Arts et Métiers (1854-1894). En J.-P. Garric É. d'Orgeix y E. Thibault (dirs.). Bibliothèques d'atelier. Edition et enseignement de l'architecture. Paris 1785-1871, Paris: INHA. Recuperado de https://journals.openedition.org/inha/3189

Picon, A. (1992a). L'invention de l'ingénieur moderne. L'École des Ponts et Chaussées 1747-1851. Paris: Presses de I'ENPC.

Picon, A. (1992b). La doctrine de Léonce Reynaud, entre rationalisme structurel et système des beaux arts. En L'invention de I'ingénieur moderne, 550-560.

Picon, A. (1992c). Apprendre à concevoir les gares: I'enseignement de Léonce Reynaud. Revue d'histoire des chemins de fer, 5-6, $51-63$.

Pillet, J. (20 septiembre 1908). École Polytechnique. Modifications proposées pour l'enseignement intérieur, AEP III, 3, a, núm. 6.

Reynaud, L. (1850-1858). Traité d'architecture (2 vols. de texto y 2 vols. de láminas). Paris: Carilian-Goeury et V. Dalmont.

Sakarovitch, J. (1994). La Géométrie descriptive, une reine déchue. En B. Belhoste, A Dahan-Dalmedico y A. Picon (dirs.). La formation polytechnicienne (pp. 77-93). Paris: Dunod.

Sakarovitch, J. (2009). "Auguste Choisy, engineering student: A technical training with a pinch of human and social sciences", ponencia en el Coloquio: Choisy 1841 1909, I'architecture et l'art de bâtir, Madrid 19-21 de noviembre de 2009, 371-386.

Savorra, M. (2005). Une storia per gli ingegneri. Corrispondenze e continuità tra Léonce Reynaud, Fernand de Dartein e Auguste Choisy. Parametro, 255(XXXV), 40-46.

Seitz, F. (1993). L'Enseignement de la construction, de l'architecture et du dessin à la fin du XIX siècle et au début du XX $x^{e}$ siècle, I'apport d'Émile Trélat et de Jules Pillet. Les Cahiers du CNAM, 2-3, 157-173.

Seitz, F. (1994). Jules Pillet (1842-1912), professeur de Constructions civiles (1894-1912).
En C. Fontanon y A. Grelon. Les professeurs du Conservatoire national des arts et métiers. Dictionnaire biographique 1794 1955 (t. 2, 339-411). Paris: Institut National de Recherche Pédagogique.

Shinn, T. (1980). Savoir scientifique et pouvoir social. L'École Polytechnique 1794-1914. Paris: Presses de la FNSP.

Szambien, W. (1984). Jean Nicolas Louis Durand De l'imitation à la norme. Paris: Picard.

Szambien, W. y Talenti, S. (1996). Durand Quaet-Faslem et Dartein ou I'influence européenne de Durand. Bulletin de la société des amis de la Bibliothèque de I'École Polytechnique. 16, 1-11. Recuperado de https://journals.openedition.org/ sabix/797?lang=en

Talenti, S. (2000a). L'histoire de l'architecture en France: émergence d'une discipline (18631914). Paris: Picard.

Talenti, S. (2000b). Dartein, Fernand de. En Saur (ed.), Allgemeines Künstlerlexikon. Munich-Leipzig: bd. XXIV.

Thibault, E. (2010). La Géométrie des émotions Les esthétiques scientifiques de I'architecture en France 1860-1950. Wavre: Mardaga.

Umbdenstock, G. (1906). Lettre à M. le Directeur des études de l'École Polytechnique, AEP, VI, 1, b, 2.

Umbdenstock, G. (1908a). Conférence d'architecture. Paris: Welhoff et Roche.

Umbdenstock, G. (1908b). La porte à travers les âges. Paris: Welhoff et Roche.

Umbdenstock, G. (1909). Du dessin et du lavis d'architecture. Paris: Welhoff et Roche.

Umbdenstock, G. (1910). Douze conférences d'architecture. Paris: École Polytechnique.

Umbdenstock, G. (1912). Architecture et dessin. Rapport du directeur des études, AEP III, 3, e, núm. 1 .

Umbdenstock, G. (1913). Rapport sur l'enseignement de l'architecture, AEP, III, 3.

Umbdenstock, G. (1922). Recueil de compositions architecturales. Paris: Ch. Massin.

Umbdenstock, G. (1930). Cours d'architecture (2 vols.). Paris: Gauthier-Villars.

Vigato, J.-C. (1994). Gustave Umbdenstock, architecture, polémique et tradition. En B. Belhoste, A. Dahan-Dalmedico y A. Picon (eds.). La formation polytechnicienne. Paris: Dunod, 265-279.

Vigato, J.-C. (1996). Gustave Umbdenstock professeur d'architecture. Bulletin de la société des amis de la Bibliothèque de l'ÉCOle Polytechnique, núm. 16, 29-49.

\section{Archivos consultados}

Archives de l'École Polytechnique (AEP). 
Thibault, E. (2018). Continuidad y transformaciones de modelos pedagógicos en la École Polytechnique (I867-|9|0). [Continuité et transformations des dispositifs pédagogiques à l'École Polytechnique (I867-1910)] (Andrés Ávila-Gómez y Diana Carolina Ruiz, trads.) (original en francés, 20 I I). Revista de Arquitectura (Bogotá), 20(2), I I0- I26. doi: http://dx.doi.org/I0.147/8/RevArq.20 I8.20.2.2 I49

\section{ANEXOS}

\section{Anexo 1. Comparación del programa de cursos de Léonce Reynaud y de Fernand de Dartein.}

Fuente: Programmes de l'enseignement intérieur de l'École Impériale Polytechnique pour l'année 1860-1861 (profesor Léonce Reynaud). Programmes de l'enseignement intérieur de l'École Impériale Polytechnique pour l'année 1868-69 (profesor Fernand de Dartein).

\begin{tabular}{|c|c|}
\hline Reynaud, programa del año 1860-61 & Dartein, programa del año 1868-69 \\
\hline $\begin{array}{l}1^{\circ} \text {. Introducción } \\
1^{\mathrm{e}} \text { parte. Elementos de los edificios }\end{array}$ & $1^{\circ}$. Introducción. piedras, cales, morteros \\
\hline \multirow{3}{*}{$\begin{array}{l}2^{\circ}, 3^{\circ} \text { y } 4^{\circ} \text {. Construcciones en piedra } \\
\text { - Materiales elementales } \\
\text { - Elementos de construcción en piedra (cimientos, muros) }\end{array}$} & $2^{\circ}$. Cimientos \\
\hline & $3^{\circ}$. Construcción de muros \\
\hline & $4^{\circ}$. Decoración de muros. Apoyos aislados \\
\hline \multirow{4}{*}{$\begin{array}{l}5^{\circ}, 6^{\circ}, 7^{\circ} \text { y } 8^{\circ} \\
\text { Columnas } \\
\text { Cariátides } \\
\text { Arcadas }\end{array}$} & $5^{\circ}$. Los órdenes arquitectónicos. Orden dórico \\
\hline & $6^{\circ}$. Orden jónico $\ldots \ldots \ldots \ldots \ldots \ldots \ldots$ \\
\hline & $7^{\circ}$. Orden corintio \\
\hline & $8^{\circ}$. Arcadas sobre arbotantes \\
\hline $9^{\circ}$ y $10^{\circ}$ & $9^{\circ}$. Ventanas, puertas \\
\hline $\begin{array}{l}\text { Puertas y ventanas } \\
\text { Cimientos } \\
\text { Áticos } \\
\text { Cornisas de remate } \\
\text { Frontones } \\
\text { Balaustradas }\end{array}$ & $10^{\circ}$. Ático, cornisas de remate, frontones, balaustradas \\
\hline \multirow{3}{*}{$\begin{array}{l}11^{\circ}, 12^{\circ} \text { y } 13^{\circ} \\
\text { Techos } \\
\text { Bóvedas }\end{array}$} & $11^{\circ}$. Techos en piedra, bóvedas, su nomenclatura \\
\hline & $12^{\circ}$. Nociones de estabilidad de bóvedas Decoración de bóvedas \\
\hline & $13^{\circ}$. Construcciones en madera, estructuras Conservación de la madera. Pans de bois. Travesaños \\
\hline \multirow{4}{*}{$\begin{array}{l}14^{\circ}, 15^{\circ}, 16^{\circ} \text { y } 17^{\circ} . \text { Construcciones en madera } \\
\text { - Materiales básicos } \\
\text { - Elementos de construcción en madera } \\
\text { - Estructuras para cubiertas }\end{array}$} & $14^{\circ}$. Entrepisos en $^{2}$ \\
\hline & $\begin{array}{l}15^{\circ} \text {. Estructuras para cubiertas } \\
\text { Diversos sistemas de cubiertas }\end{array}$ \\
\hline & $16^{\circ}$. Carpinterías, parqués, revestimientos, puertas \\
\hline & $17^{\circ}$. Construcciones metálicas, hierro, hierro fundido, ensamblajes en hierro \\
\hline $18^{\circ}$ Carpinterías & $\begin{array}{l}18^{\circ} \text {. Ensamblajes en hierro fundido } \\
\text { Entrepisos metálicos }\end{array}$ \\
\hline $\begin{array}{l}19^{\circ} \text {. Construcciones en hierro } \\
\text { - Materiales elementales } \\
\text { - Elementos de construcción en hierro }\end{array}$ & $19^{\circ}$. Cubiertas metálicas \\
\hline \multirow{5}{*}{$\begin{array}{l}2^{\mathrm{e}} \text { parte. Combinación de elementos y composición de edificios } \\
\text { Combinación de elementos de edificios } \\
20^{\circ}, 21^{\circ}, 22^{\circ}, 23^{\circ}, 24^{\circ} \text { et } 25^{\circ} \\
\text { - Consideraciones generales } \\
\text { - Principales componentes de edificios (portales, pórticos, } \\
\text { vestíbulos, escaleras) }\end{array}$} & $\begin{array}{l}21^{\circ} \text {. Composición de edificios } \\
\text { Pórticos }\end{array}$ \\
\hline & 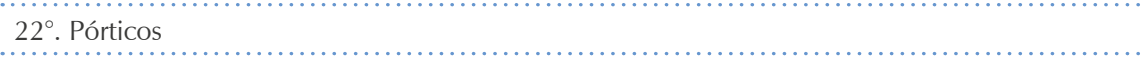 \\
\hline & $23^{\circ}$. Portales \\
\hline & $24^{\circ}$. Vestíbulos \\
\hline & $25^{\circ}$. Escaleras \\
\hline \multirow[b]{2}{*}{$\begin{array}{l}26^{\circ}, 27 \text { y } 28^{\circ} \\
\text { - Salas techadas } \\
\text { - Salas abovedadas } \\
\text { - Patios } \\
\text { - Plazas públicas } \\
\text { - Jardines y fuentes }\end{array}$} & $26^{\circ}$. Salas romanas techadas y abovedadas Primeras basílicas cristianas \\
\hline & $28^{\circ}$. Estilo romano-bizantino \\
\hline \multirow{6}{*}{$\begin{array}{l}\text { Composición de edificios } \\
29^{\circ}, 30^{\circ}, 31^{\circ}, 32^{\circ}, 33^{\circ} \text { y } 34^{\circ} \\
\text { - Programas y proyectos de edificios de diversa naturaleza }\end{array}$} & $29^{\circ}$. Estilo ojival [gótico] \\
\hline & $\begin{array}{l}30^{\circ} . \text { Renacimiento } \\
\text { Arquitectura moderna }\end{array}$ \\
\hline & 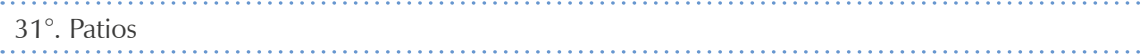 \\
\hline & $32^{\circ}$ Jardines, fuentes de agua, composición de edificios, proyecto de biblioteca \\
\hline & $33^{\circ}$ Residencias particulares, casas urbanas y de campo, hoteles \\
\hline & $34^{\circ}$. Prisiones \\
\hline \multirow{6}{*}{$\begin{array}{l}\text { Nociones sobre vías de comunicación } \\
35^{\circ}, 36^{\circ}, 37^{\circ}, 38^{\circ}, 39^{\circ} \text { y } 40^{\circ} \\
\text {-Consideraciones generales } \\
\text {-Carreteras } \\
\text {-Vías férreas } \\
\text {-Canales } \\
\text {-Navegación en lechos fluviales } \\
\text {-Obras de arte relacionadas con la implementación de vías de } \\
\text { comunicación }\end{array}$} & $35^{\circ}$. Hospitales \\
\hline & $36^{\circ}$. Cuarteles, puertas de acceso a la ciudad, entradas monumentales \\
\hline & $37^{\circ}$. Obras públicas, vías de comunicación, carreteras \\
\hline & 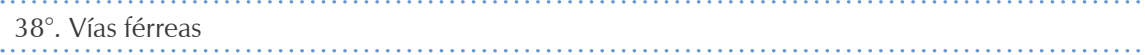 \\
\hline & $39^{\circ}$. Vías navegables, canales \\
\hline & $\begin{array}{l}40^{\circ} \text {. Obras de arte } \\
\text { Puentes } \\
\text { Viaductos } \\
\text { Acueductos }\end{array}$ \\
\hline
\end{tabular}


Anexo 2.

"Composición de edificios. Estudio de un proyecto". Extracto de Fernand de Dartein, Cours d'architecture, École Polytechnique, 1909.

- Trabajo preliminar -Examen crítico del programa. -Informaciones relativas al programa, suministradas por monumentos análogos. -Estudio de tales monumentos. -Mejoras sugeridas a partir del estudio.

- Planos -Esbozos propuestos libremente, pequeños pero sin escala específica. -Vista del conjunto. -Distribución de los servicios al interior de los edificios, si se trata de un conjunto, y por pisos. -Circulaciones principales.

- Estudio de la planta, primero en una escala reducida, y luego en una escala mayor.

- Cantidad y distribución de los componentes. -Distribución. -Circulaciones. -Posición disposición de las escaleras.

- Cortes -Estudiar los cortes antes de finalizar la planta. -Construcción. -Cimientos. -Sótanos. -Altura de pisos. -Muros. -Columnas. -Bóvedas. -Techo. -Chimeneas. -Cubierta.

- Elevaciones -Esquema original del conjunto, y modificaciones realizadas, si las hay, de acuerdo con los estudios precedentes. -Estudio del conjunto a una escala intermedia.

- Perspectivas para comprender el aspecto real y el valor de los voladizos. Estudio de la armonía y la belleza de las formas.

- Estudio a gran escala de los detalles, y, si es posible, a veces a tamaño real. Modelos en yeso de los principales elementos empleados en la escultura, los capiteles, los emblemas, las consolas, etc.

Anexo 3.

Gustave Umbdenstock. Doce conferencias de arquitectura, École Polytechnique, año 1911-1912

1. Historia y filosofía de la arquitectura.

2. Composición arquitectónica y valor expresivo de las formas geométricas.

3. Ángulo obtuso. Líneas paralelas. Líneas secantes.

4. La curva.

5 y 6. Aplicación del valor expresivo de la curva en construcciones en madera y hierro.

7. Estudio de superficies. Lo utilitario, lo decorativo, lo monumental.

8. La concepción monumental griega y romana.

9. Arquitectura gótica.

10. Arquitectura civil del medioevo.

11. Suelos, chimeneas, pórticos y aleros, techos.

12. Teoría y elementos de la composición decorativa.

\section{Anexo 4.}

"Arquitectura. Programa establecido por el Conseil de Perfectionnement durante las sesiones de los días 5 de abril y 3 de mayo de 1913"

Primer año (12 lecciones)

Introducción: Definición y objeto de la Arquitectura. Estructura del curso.

Nociones de historia de la arquitectura desde la Antigüedad hasta nuestros días.

a) Nociones elementales sobre la arquitectura de Egipto y de Persia. Formas y proporciones de sus diferentes elementos.

b) Arquitectura griega. Formas y proporciones de sus diferentes órdenes.

c) Arquitectura durante la Antigüedad romana. La basílica. La sala de termas.

d) Arquitectura bizantina. Formas y proporciones de sus diversos elementos.

e) Arquitectura romana. Formas y proporciones de sus diversos elementos.

f) Arquitectura ojival [gótica]. Formas y proporciones de sus diversos elementos en Francia y en Europa occidental.

g) Arquitectura del Renacimiento en Italia y Francia.

h) Arquitectura clásica.

Segundo año (6 sesiones) (que luego serían 12 por disposición del ministro, según se indica en el comunicado del 14 de mayo de 1913).

Arquitectura contemporánea, en Francia y en el extranjero.

El programa moderno y los nuevos materiales. Las leyes de su estética y de su carácter.

Ejercicios

- Antes de la sesión, los alumnos reciben una hoja sobre la cual aparecen litografiados los bocetos.

- Durante la sesión, los alumnos dibujan sobre la hoja suministrada aquellos bosquejos que el profesor traza en el tablero, y que no se encuentran reproducidos en la respectiva hoja. Los bosquejos que allí figuran van acompañados de títulos, y en algunos casos de cotas. Después de la sesión, los alumnos reciben una síntesis redactada por el profesor. Los alumnos deben completar los croquis propuestos por el profesor. Estos ejercicios son recuperados por el profesor al día siguiente con el fin de ser corregidos y calificados.

- Al cabo de dicha corrección, las hojas de croquis deben ser anexadas al texto de las sesiones. 


\section{Enfoque y alcance}

La Revista de Arquitectura (Bogotá) (ISSN 1657-0308 Impresa y E-ISSN 2357-626X en línea) es una publicación seriada de acceso abierto, arbitrada mediante revisión por pares (doble ciego) e indexada, en donde se publican resultados de investigación originales e inéditos.

Está dirigida a la comunidad académica y profesional de las áreas afines a la disciplina. Es editada por la Facultad de Diseño y el Centro de Investigaciones (CIFAR) de la Universidad Católica de Colombia en Bogotá (Colombia).

La principal área científica a la que se adscribe la Revista de Arquitectura (Bogotá) según la OCDE es:

Gran área: 6. Humanidades

Área: 6.D. Arte

Disciplina: 6D07. Arquitectura y Urbanismo

También se publican artículos de las disciplinas como 2A02, Ingeniería arquitectónica; 5G03, Estudios urbanos (planificación y desarrollo); 6D07, Diseño.

Los objetivos de la Revista de Arquitectura (Bogotá) son:

- Promover la divulgación y difusión del conocimiento generado a nivel local, nacional e internacional

- Conformar un espacio para la construcción de comunidades académicas y la discusión en torno a las secciones definidas.

- Fomentar la diversidad institucional y geográfica de los autores que participan en la publicación.

- Potenciar la discusión de experiencias e intercambios científicos entre investigadores y profesionales.

- Contribuir a la visión integral de la arquitectura, por medio de la concurrencia y articulación de las secciones mediante la publicación de artículos de calidad.

- Publicar artículos originales e inéditos que han pasado por revisión de pares, para asegurar que se cumplen las normas éticas, de calidad, validez científica, editorial e investigativa.

- Fomentar la divulgación de las investigaciones y actividades desarrolladas en la Universidad Católica de Colombia.
Palabras clave de la Revista de Arquitectura (Bogotá): arquitectura, diseño, educación arquitectónica, proyecto y construcción, urbanismo.

Idiomas de publicación: español, inglés, portugués y francés.

Título abreviado: Rev. Arquit.

Titulo corto: RevArq

\section{Políticas de sección}

La revista se estructura en tres secciones correspondientes a las líneas de investigación activas y aprobadas por la institución, y dos complementarias, que presentan dinámicas propias de la Facultad de Diseño y las publicaciones relacionadas con la disciplina.

Cultura y espacio urbano. En esta sección se publican los artículos que se refieren a fenómenos sociales en relación con el espacio urbano, atendiendo aspectos de la historia, el patrimonio cultural y físico, y la estructura formal de las ciudades y el territorio.

Proyecto arquitectónico y urbano. En esta sección se presentan artículos sobre el concepto de proyecto, entendido como elemento que define y orienta las condiciones proyectuales que devienen en los hechos arquitectónicos o urbanos, y la forma como estos se convierten en un proceso de investigación y nuevo de conocimiento. También se presentan proyectos que sean resultados de investigación, los cuales se validan por medio de la ejecución y transformación en obra construida del proceso investigativo. También se contempla la publicación de investigaciones relacionadas con la pedagogía y didáctica de la arquitectura, el urbanismo y el diseño.

Tecnología, medioambiente y sostenibilidad. En esta sección se presentan artículos acerca de sistemas estructurales, materiales y procesos constructivos, medioambiente y gestión, relacionados con los entornos social-cultural, ecológico y económico.

Desde la Facultad. En esta sección se publican artículos generados en la Facultad de Diseño, relacionados con las actividades de docencia, extensión, formación en investigación o internacionalización, las cuales son reflejo de la dinámica y de las actividades realizadas por docentes, estudiantes y egresados; esta sección no puede superar el $20 \%$ del contenido.

Textos. En esta sección se publican reseñas, traducciones y memorias de eventos relacionados con las publicaciones en Arquitectura y Urbanismo.

\section{A Frecuencia de publicación}

Desde 1999 y hasta el 2015, la Revista de Arquitectura (Bogotá) publicó un volumen al año, a partir del 2016 se publicarán dos números por año en periodo anticipado, enero-junio y julio-diciembre, pero también maneja la publicación anticipada en línea de los artículos aceptados (versión Post-print del autor).

La Revista de Arquitectura (Bogotá) se divulga mediante versiones digitales (PDF, HTML, EPUB, XML) e impresas con un tiraje de 700 ejemplares, los tiempos de

Universidad Católica de Colombia (2018,
julio-diciembre).
Revista de Arquitectura (Bogotá),
20(2), I-I28. Doi: I0.I47/8
ISSN: 1657-0308
E-ISSN: 2357-626X
Especificaciones:
Formato: 34 x $24 \mathrm{~cm}$
Papel: Mate II5 g
Tintas: Negro y policromía

producción de estas versiones dependerán de los cronogramas establecidos por la editorial.

Los tiempos de recepción-revisión-aceptación pueden tardar entre seis y doce meses dependiendo del flujo editorial de cada sección y del proceso de revisión y edición adelantado.

Con el usuario y contraseña asignados, los autores pueden ingresar a la plataforma de gestión editorial y verificar el estado de revisión, edición o publicación del artículo.
A Canje

La Revista de Arquitectura está interesada en establecer canje con publicaciones académicas, profesionales o científicas del área de Arquitectura y Urbanismo, como medio de reconocimiento y discusión de la producción científica en el campo de acción de la publicación.

\section{Mecanismo}

Para establecer canje por favor descargar, diligenciar y enviar el formato: RevArq FP20 Canjes 
Universidad Católica de Colombia

Presidente

Édgar Gómez Betancourt

Vicepresidente - Rector

Francisco José Gómez Ortiz

Vicerrector Jurídico

Edwin de Jesús Horta Vásquez

Vicerrector Administrativo

Édgar Gómez Ortiz

Vicerrector Académico

Elvers Medellín Lozano

Director de Investigaciones

Edwin Daniel Durán Gaviria

Directora Editorial

Stella Valbuena García

\section{Facultad de Diseño}

Decano

Werner Gómez Benítez

Director de docencia

Jorge Gutiérrez Martínez

Directora de extensión

Adriana Pedraza Pacheco

Director de investigación

Hernando Verdugo Reyes

Director de gestión de calidad

Augusto Forero La Rotta

Comité asesor externo

Facultad de Diseño

Édgar Camacho Camacho

Martha Luz Salcedo Barrera

Samuel Ricardo Vélez
Facultad de Diseño

Centro de Investigaciones - CIFAR
Revista de acceso abierto

arbitrada e indexada

Publindex: Categoría B. Índice Bibliografico Nacional IBN.

Esci: Emerging Source Citation Index.

Doaj: Directory of Open Access Journals.

Redalyc: Red de Revistas Cientificas de América Latina y el Caribe, España y Portugal.

SciELO: Scientific Electronic Library Online - Colombia

Redib: Red Iberoamericana de Innovación y Conocimiento Cientifico.

Ebsco: EBSCOhost Research Databases.

Clase: Base de datos bibliográfica de revistas de ciencias sociales y

humanidades.

Latindex: Sistema Regional de Información en Línea para Revistas

Cientificas de América Latina, el Caribe, España y Portugal (Directorio

y catálogo).

Dialnet: Fundación Dialnet - Biblioteca de la Universidad de La Rioja.

LatinRev: Red Latinoamericana de Revistas Académicas en Ciencias

Sociales $y$ Humanidades.

Proquest: ProQuest Research Library.

Miar: Matrix for the Analysis of Journals.

Sapiens Research: Ranking de las mejores revistas colombianas según visibilidad internacional.

Actualidad Iberoamericana: (Índice de Revistas) Centro de Informació Tecnológica (CIT).

Google Scholar

Arla: Asociación de Revistas latinoamericanas de Arquitectura.

Editorial

Av. Caracas $N^{\circ} 46-72$, piso

Teléfono: 3277300 Ext. 5145

editorial@ucatolica.edu.co

www.ucatolica.edu.co

http://publicaciones.ucatolica.edu.co/

Impresión:

JAVEGRAF

Calle 46A No82-54 Int. 2

Bogotá, D. C., Colombia

http://www.javegraf.com.co/index.php

Agosto de 2018

\section{Revista de Arquitectura \\ (Bogotá)}

Director

Werner Gómez Benítez

Editor

César Eligio-Triana

Editores de sección

(1) Myriam Stella Díaz Osorio

(1) Carolina Rodríguez-Ahumada

(1) Anna Maria Cereghino Fedrigo

\section{Equipo editorial}

Coordinadora editorial

María Paula Godoy Casasbuenas mpgodoy@ucatolica.edu.co

Diseño y montaje

Juanita Isaza

juanaisaza@gmail.com

Traductoras

Inglés

Erika Tanacs

etanacs25@gmail.com

Portugués

Roanita Dalpiaz

roanitad@gmail.com

Correctora de estilo

María José Díaz Granados M.

mariajose_dgm@yahoo.com.co

Página Web

Centro de investigaciones (CIFAR)

Distribución y canjes

Claudia Álvarez Duquino

calvarez@ucatolica.edu.co
Comité editorial y científico

Cultura y espacio urbano

Carlos Mario Yory, PhD

Universidad Católica de Colombia. Bogotá, Colombia

Sonia Berjman, $\mathrm{PhD}$

ICOMOS-IFLA, Buenos Aires, Argentina

Juan Carlos Pérgolis, MSc Universidad Piloto de Colombia. Bogotá, Colombia

Beatriz García Moreno, PhD

Universidad Nacional de Colombia. Bogotá, Colombia

Proyecto arquitectónico y urbano

Jean-Philippe Garric, PhD, HDR

Université Paris I Panthéon-Sorbonne. Paris, Francia

Debora Domingo Calabuig, PhD

Universidad Politécnica de Valencia, España

Dania González Couret, PhD

Universidad Tecnológica de La Habana, Cuba

Hugo Mondragón López, PhD Pontificia Universidad Católica de Chile. Santiago, Chile

Juan Pablo Duque Cañas, PhD

Universidad Nacional de Colombia. Bogotá, Colombia

Tecnología, medioambiente y sostenibilidad

Mariano Vázquez Espí, PhD

Universidad Politécnica de Madrid, España

Denise Helena Silva Duarte, PhD Universidade de São Paulo (USP), Brasil

Luis Carlos Herrera Sosa, PhD Universidad Autónoma de Ciudad Juárez, México

Claudio Varini, PhD

Universidad Católica de Colombia. Bogotá, Colombia

Luis Gabriel Gómez Azpeitia, PhD Universidad de Colima. Colima, México 


\section{Contenido}

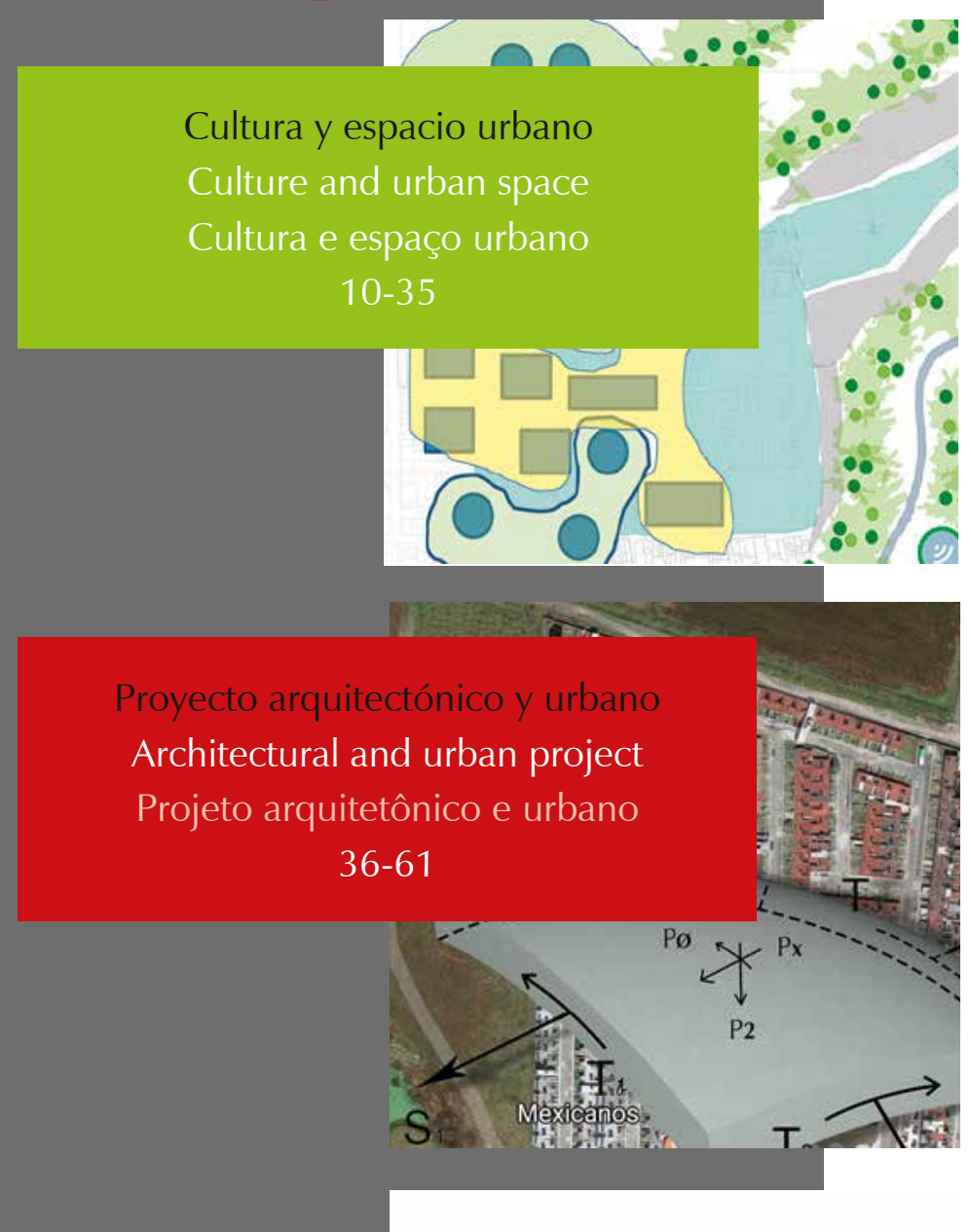

Tecnología, medioambiente

y sostenibilidad

Technology, environment and sustainability

Tecnologia, meio ambiente e sustentabilidade

62-89
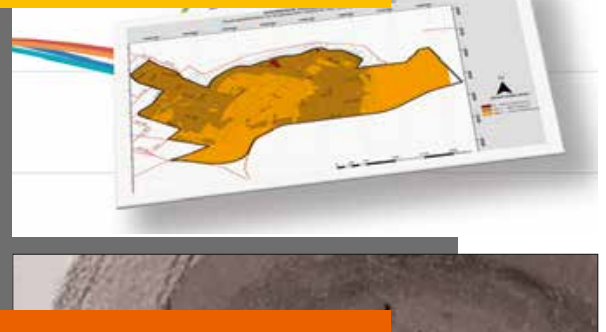

Desde la Facultad

From the Faculty

Da faculdade

90-109
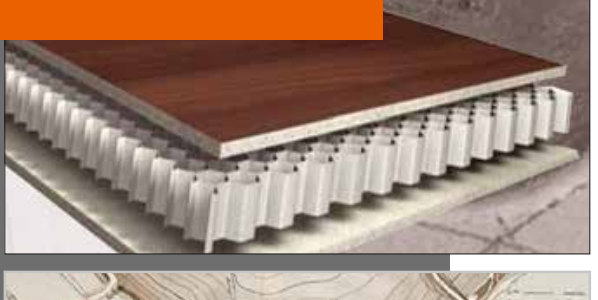

Textos

Texts

Textos

110-126

Los artículos científicos como herramienta de aprendizaje en las escuelas de arquitectura

Carolina Rodríguez-Ahumada

Pág. 3 ES

Paisaje urbano y espacio público como expresión de la vida cotidiana

Morella Briceño-Ávila

Pág. 10

\section{ES EN}

Habitar la quebrada: conformación de gradientes en las trazas vernaculares de los sectores altos de Valparaíso

\section{Omar Eduardo Cañete-Islas}

Juan Luis Moraga-Lacoste

Felipe Mateo López-Flores

Pág. 20

ES

Láminas cilíndricas en la arquitectura colombiana del siglo XX

Jorge Galindo-Díaz

Pág. 36

\section{ES EN}

Retórica simbólica en el espacio arquitectónico

Una mirada antropológica de la casa en la

sobremodernidad

Eska Elena Solano-Meneses

Pág. 51

ES

Ecoenvolventes: análisis del uso de fachadas ventiladas en clima cálido-húmedo

\footnotetext{
Sara Luciani-Mejía

Rodrigo Velasco-Gómez

Roland Hudson
}

Pág. 62

ES

Estrategias metodológicas de análisis urbano frente al cambio climático

Matriz para el diseño adaptativo en asentamientos informales

Adriana Patricia López-Valencia

Oswaldo López-Bernal

Pág. 78

ES

Muro panel térmico estructural compuesto

en guadua y cartón

Modelo experimental aplicado al clima de

la zona cafetera

Renato Cassandro-Cajiao

Pág. 90

\section{ES EN}

Continuidad y transformaciones de modelos

pedagógicos en la École Polytechnique (1867-1910)

Estelle Thibault

Traductores

Andrés Ávila-Gómez

Diana Carolina Ruiz

Pág. 110

ES 
La postulación de un artículo a la Revista de Arquitectura (Bogotá) indica que- el o los autores certifican que conocen y aceptan la política editorial, para lo cual firmarán en original y remitirán el formato RevArq FP00 Carta de originalidad.

La Revista de Arquitectura (Bogotá) maneja una política de Autoarchivo VERDE, según las directrices de SHERPA/RoMEO, por lo cual el autor puede:

- Pre-print del autor: Archivar la versión pre-print (la versión previa a la revisión por pares

- Post-print del autor: Archivar la versión post-print (la versión final posterior a la revisión por pares

- Versión de editor/PDF: Archivar la versión del editor - PDF/HTML/XLM en la maqueta de la Revista de Arquitectura (Bogotá).

El Autoarchivo se debe hacer respetando la licencia de acceso abierto, la integridad y la imagen de la Revista de Arquitectura (Bogotá), también se recomienda incluir la referencia, el vínculo electrónico y el DOI.

El autor o los autores son los titulares del Copyright (c) del texto publicado y la Editorial de la Revista de Arquitectura (Bogotá) solicita la firma de una autorización de reproducción del artículo (RevArq FP03 Autorización reproducción), la cual se acoge a la licencia CC, donde se expresa el derecho de primera publicación de la obra.

La Revista de Arquitectura (Bogotá) se guía por las normas internacionales sobre propiedad intelectual y derechos de autor, y de manera particular el artículo 58 de la Constitución Política de Colombia, la Ley 23 de 1982 y el Acuerdo 172 del 30 de septiembre de 2010 (Reglamento de propiedad intelectual de la Universidad Católica de Colombia)

Para efectos de autoría y coautoría de artículos se diferencian dos tipos: "obra en colaboración" y "obra colectiva". La primera es aquella cuya autoría corresponde a todos los participantes al ser fruto de su trabajo conjunto. En este caso, quien actúa como responsable y persona de contacto debe asegurar que quienes firman como autores han revisado y aprobado la versión final, y dan consentimiento para su divulgación. La obra colectiva es aquella en la que, aunque participan diversos colaboradores, hay un autor que toma la iniciativa la coordinación y realización de dicha obra. En estos casos, la autoría corresponderá a dicha persona (salvo pacto en contrario) y será suficiente únicamente con su autorización de divulgación.

El número de autores por artículo debe estar justificado por el tema, la complejidad y la extensión, y no deberá ser superior a la media de la disciplina, por lo cual se recomienda que no sea mayor de cinco. El orden en que se enuncien corresponderá a los aportes de cada uno a la construcción del texto, se debe evitar la autoría ficticia o regalada. Si se incluyen más personas que trabajaron en la investigación se sugiere que sea en calidad de colaboradores o como parte de los agradecimientos. La Revista de Arquitectura (Bogotá) respetará el número y el orden en que figuren en el original remitido. Si los autores consideran necesario, al final del artículo pueden incluir una breve descripción de los aportes individuales de cada uno de firmantes.

La comunicación se establece con uno de los autores, quien a su vez será el responsable de informar a los demás autores de las notificaciones emitidas por la Revista de Arquitectura (Bogotá).

En virtud de mantener el equilibro de las secciones y las mismas oportunidades para todos los participantes, un mismo autor puede postular dos o más artículos de manera simultánea; si la decisión editorial es favorable y los artículos son aceptados, su publicación se realizará en números diferentes.

\section{A Acceso abierto}

La Revista de Arquitectura (Bogotá), en su misión de divulgar la investigación y apoyar el conocimiento y la discusión en los campos de interés, proporciona acceso abierto, inmediato e irrestricto a su contenido de manera gratuita mediante la distribución de ejemplares impresos y digitales. Los interesados pueden leer, descargar, guardar, copiar y distribuir, imprimir, usar, buscar o referenciar el texto completo o parcial de los artículos o la totalidad de la Revista de Arquitectura (Bogotá).

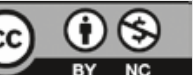

Esta revista se acoge a la licencia Creative Commons (CC BY NC de Atribución - No comercial 4.0 Internacional): "Esta licencia permite a otros entremezclar, ajustar y construir a partir de su obra con fines no comerciales, y aunque en sus nuevas creaciones deban reconocerle su autoría y no puedan ser utilizadas de manera comercial, no tienen que estar bajo una licencia con los mismos términos".

La Revista de Arquitectura es divulgada en centros y grupos de investigación, en bibliotecas y universidades, y en las principales facultades de Arquitectura mediante acceso abierto a la versión digital y suscripción anual al ejemplar impreso o por medio de canje, este último se formaliza mediante el formato RevArq FP20 Canjes

Para aumentar su visibilidad y el impacto de los artículos, se envían a bases de datos y sistemas de indexación y resumen (SIR) y, asimismo, pueden ser consultados y descargados en la página web de la revista.

La Revista de Arquitectura no maneja cobros, tarifas o tasas de publicación de artículo (Article Processing Charge-APC), o por el sometimiento de textos a la publicación.

\section{(1)Ética y buenas prácticas}

La Revista de Arquitectura se compromete a cumplir y respetar las normas éticas en todas las etapas del proceso de publicación. Los autores de los artículos publicados darán cumplimiento a los principios éticos contenidos en las diferentes declaraciones y legislaciones sobre propiedad intelectual y derechos de autor específicos del país donde se realizó la investigación. En consecuencia, los autores de los artículos postulados y aceptados para publicar, que presentan resultados de investigación, deben firmar la declaración de originalidad (formato RevArq FP00 Carta de originalidad).

La Revista de Arquitectura reconoce y adopta los principios de transparencia y buenas prácticas descritos por COPE, "Principles of Transparency and Best Practice in Scholarly Publishing" (2015).

El equipo editorial tiene la obligación de guardar la confidencialidad acerca de los artículos recibidos, y abstenerse de usar en sus propias investigaciones datos, argumentos o interpretaciones hasta tanto el artículo no sea publicado. También debe ser imparcial y gestionar los artículos de manera adecuada y en los plazos establecidos. La selección de revisores se hará con objetividad y estos deberán responder a la temática del artículo.

El editor, los autores y los revisores deben seguir las normas éticas internacionales definidas por el Committee on Publication Ethics (COPE), con el fin de evitar casos de:

- Fabricación, falsificación u omisión de datos.

- Plagio y autoplagio.

- Publicación redundante, duplicada o fragmentada.

- Omisión de referencias a las fuentes consultadas.

- Utilización de contenidos sin permiso o sin justificación.

- Apropiación individual de autoría colectiva.

- Cambios de autoría.

- Conflicto de interés (CDI) no revelado o declarado.

- Otras que pudieran surgir en el proceso de investigación y publicación. La fabricación de resultados se genera al mostrar datos inventados por los autores; la falsificación resulta cuando los datos son manipulados y cambiados a capricho de los autores; la omisión se origina cuando los autores ocultan deliberadamente un hecho o dato. El plagio se da cuando un autor presenta como ideas propias datos creados por otros. Los casos de plagio son los siguientes: copia directa de un texto sin entrecomillar o citar la fuente, modificación de algunas palabras del texto, paráfrasis y falta de agradecimientos; el autoplagio se da cuando el mismo autor reutiliza material propio que ya fue publicado, pero sin indicar la referencia al trabajo anterior. La revista se apoya en herramientas digitales que detectan cualquiera de estos casos en los artículos postulados, y es labor de los editores y revisores velar por la originalidad y fidelidad en la citación. La publicación redundante o duplicada se refiere a la copia total, parcial o alterada de un trabajo ya publicado por el mismo autor

En caso de sospechar de alguna mala conducta se recomienda seguir los diagramas de flujo elaborados por COPE (2008), con el fin de determinar las acciones correspondientes.

La Revista de Arquitectura se reserva el derecho de retractación de publicación de aquellos artículos que, posterior a su publicación, se demuestre que presentan errores de buena fe, o cometieron fraudes o malas prácticas científicas. Esta decisión se apoyará en "Retraction Guidelines" (COPE, 2009). Si el error es menor, este se podrá rectificar mediante una nota editorial de corrección o una fe de erratas. Los autores también tienen la posibilidad de solicitar la retractación de publicación cuando descubran que su trabajo presenta errores graves. En todos los casos se conservará la versión electrónica y se harán las advertencias de forma clara e inequívoca.

\section{A Privacidad y manejo de la información.} Habeas Data

Para dar cumplimiento a lo previsto en el artículo 10 del Decreto 1377 de 2013, reglamentario de la Ley 1581 de 2012, y según el Acuerdo 002 del 4 de septiembre de 2013 de la Universidad Católica de Colombia, "por el cual se aprueba el manual de políticas de tratamiento de datos personales":

La Universidad Católica de Colombia, considerada como responsable o encargada del tratamiento de datos personales, manifiesta que los datos personales de los autores, integrantes de los comités y pares revisores, se encuentran incluidos en nuestras bases de datos; por lo anterior, y en cumplimiento de las disposiciones legales vigentes, la Universidad solicitará siempre su autorización, para que en desarrollo de sus funciones propias como Institución de Educación Superior, en especial las relacionadas con la docencia, la extensión y la investigación, la Universidad Católica de Colombia pueda recolectar, recaudar, almacenar, usar, circular, suprimir, procesar, intercambiar, compilar, dar tratamiento, actualizar, transmitir o transferir a terceros países y disponer de los datos que le han suministrado y que han sido incorporados en las bases de datos de todo tipo que reposan en la Universidad.

La Universidad Católica de Colombia queda autorizada, de manera expresa e inequívoca, en los términos señalados por el Decreto 1377 de 2013, para mantener y manejar la información de nuestros colaboradores (autores, integrantes de los diferentes comités y pares revisores); así mismo, los colaboradores podrán ejercer sus derechos a conocer, actualizar, rectificar y suprimir sus datos personales, para lo cual se han dispuesto las siguientes cuentas de correo electrónico: 
La Revista de Arquitectura (Bogotá) recibe artículos de manera permanente. Los artículos se procesan a medida que se postulan, dependiendo el flujo editorial de cada sección.

El idioma principal es el español, y como opcionales están definidos el inglés, el portugués y el francés; los textos pueden ser escritos y presentados en cualquiera de estos.

Los artículos postulados deben corresponder a las categorías universalmente aceptadas como producto de investigación, ser originales e inéditos y sus contenidos responder a criterios de precisión, claridad y brevedad.

Como punto de referencia se pueden tomar las tipologías y definiciones del Índice Bibliográfico Nacional, Publindex (2010) que se describen la continuación:

1. Artículo de revisión: documento resultado de una investigación terminada donde se analizan, sistematizan e integran los resultados de investigaciones publicadas o no publicadas, sobre un campo en ciencia o tecnología, con el fin de dar cuenta de los avances y las tendencias de desarrollo. Se caracteriza por presentar una cuidadosa revisión bibliográfica de por lo menos 50 referencias.
2. Artículo de investigación científica y tecnológica: documento que presenta, de manera detallada, los resultados originales de proyectos terminados de investigación. La estructura generalmente utilizada contiene cuatro apartes importantes: introducción, metodología, resultados y conclusiones.

3. Artículo de reflexión: documento que presenta resultados de investigación terminada desde una perspectiva analítica, interpretativa o crítica del autor, sobre un tema específico, recurriendo a fuentes originales.

Adicional a estas tipologías, se pueden presentar otro tipo de artículos asociados a procesos de investigación-creación y/o investigación proyectual. En todos los casos se debe presentar la información suficiente para que cualquier investigador pueda reproducir la investigación y confirmar o refutar las interpretaciones defendidas y sea evidente el aporte a la disciplina.

En todos los casos se debe presentar la información suficiente para que cualquier investigador pueda reproducir la investigación y confirmar o refutar las interpretaciones defendidas.

\section{(A) Instrucciones para postular artículos}

Postular el artículo en la página web de la Revista de Arquitectura (Bogotá) y adjuntar comunicación escrita dirigida al editor RevArq_FP00 Carta de originalidad (debidamente firmada por todos los autores en original); de igual manera, se debe diligenciar el formato de hoja de vida RevArq FP01 Hoja de Vida (una por cada autor).

En la comunicación escrita el autor expresa que conoce y acepta la política editorial de la Revista de Arquitectura (Bogotá), que el artículo no está postulado para publicación simultáneamente en otras revistas u órganos editoriales y que no existe conflicto de intereses (ver modelo RevArq FP06 CDI) y que, de ser aceptado, concederá permiso de primera publicación, no exclusiva a nombre de la Universidad Católica de Colombia como editora de la revista.

Los artículos deben tener en cuenta las siguientes recomendaciones:

- En la primera página del documento se debe incluir:

Tírulo: no exceder 15 palabras

Subtítulo: opcional, complementa el título o indica las principales subdivisiones del texto.

Nombre del autor o autores: nombres y apellidos completos o según modelo de citación adoptado por el autor para la normalización de los nombres del investigador. Como nota al pie (máximo 150 palabras): formación académica, experiencia profesional e investigativa, vinculación laboral, código https://orcid.org/, premios o reconocimientos, publicaciones representativas e información de contacto, correo electrónico.

Filiación institucional: debajo del nombre se debe declarar la ins-titución en la cual se desarrolló el producto, de la cual recibió apoyo o aquella que respalda el trabajo investigativo.

Resumen: debe ser analítico, se redacta en un solo párrafo, da cuenta del tema, el objetivo, la metodología, los resultados y las conclusiones; no debe exceder las 150 palabras.

Palabras clave: cinco palabras o grupo de palabras, ordenadas alfabéticamente y que no se encuentren en el título o subtítulo; estas sirven para clasificar temáticamente al artículo. Se recomienda emplear principalmente palabras definidas en el tesauro de la Unesco (http://databases. unesco.org/thessp/), en el tesauro de Arte \& Arquitectura (C) (www.aatespanol.cl), o Vitruvio (http://vocabularyserver.com/vitruvio/)

También se recomienda incluir título, resumen y palabras clave en segundo idioma.

- La segunda página y siguientes deben tener en cuenta:

El cuerpo del artículo se divide en: Introducción, Metodología, Resultados y Discusión de resultados; posteriormente se presentan las Conclusiones, y luego las Referencias bibliográficas y los Anexos (método IMRYD). Las tablas y figuras se deben incorporar en el texto.

Descripción del proyecto de investigación: en la introducción se debe describir el tipo de artículo y brevemente el marco investigativo del cual es resultado y diligenciar el formato (RevArq FP02 Info Proyectos de Investigación).

TEXTO: todas las páginas deben venir numeradas y con el título de artículo en la parte superior de la página. Márgenes de $3 \mathrm{~cm}$ por todos los lados, interlineado doble, fuente Arial o Times New Roman de 12 puntos, texto justificado (Ver plantilla para presentación de artículos). La extensión de los artículos debe ser de alrededor de 5.000 palabras ( \pm 20 páginas, incluyendo gráficos, tablas, referencias, etc.); como mínimo 3.500 y máximo 8.000 palabras. Se debe seguir el estilo vigente y recomendado en el Manual para Publicación de la American Psychological Association (APA). (Para mayor información véase http://www.apastyle.org/)
Citas y notas al pie: las notas aclaratorias o notas al pie no deben exceder cinco líneas o 40 palabras, de lo contrario estas deben ser incorporadas al texto general. Las citas pueden ser:

Corta: (con menos de 40 palabras) se incorporan al texto y pueden ser: textuales (se encierran entre dobles comillas), parafraseo o resumen (se escriben en palabras del autor dentro del texto).

Cita textual extensa: (mayor de 40 palabras) debe ser dispuesta en un renglón y un bloque independiente con sangrías y omitiendo las comillas, no olvidar en ningún caso la referencia del autor (Apellido, año, página).

Referencias: como modelo para la construcción de referencias se emplea el estilo recomendado en el Manual para Publicación de la American Psychological Association (APA) (http://www.apastyle.org/).

Siglas: en caso de emplear siglas en el texto, las figuras o las tablas, se debe proporcionar la equivalencia completa la primera vez que se empleen y encerrarlas entre paréntesis. En el caso de citar personajes reconocidos se deben colocar nombres o apellidos completos, nunca emplear abreviaturas.

Figuras y tablas: las figuras (gráficos, diagramas, ilustraciones, planos, mapas o fotografías) y las tablas deben ir numeradas y contener título o leyenda explicativa relacionada con el tema del artículo, que no exceda las 15 palabras (Figura 1. xxxxx, Tabla 1. xxxx, etc.) y la procedencia (fuente: autor o fuente, año, página). Estas se deben referenciar en el texto de forma directa o entre paréntesis; se recomienda hacerlo con referencias cruzadas.

También se deben entregar en medio digital, independiente del texto, en formatos editables o abiertos. La marcación de los archivos debe corresponder a la incluida en el texto. Según la extensión del artículo se deben incluir de 5 a 10 gráficos. Ver guía para la búsqueda de imágenes de dominio público o bajo licencias Creative Commons (CC).

El autor es el responsable de adquirir los derechos o las autorizaciones de reproducción a que haya lugar para imágenes o gráficos tomados de otras fuentes, así como de entrevistas o material generado po colaboradores diferentes a los autores; de igual manera, se debe garantizar la protección de datos e identidades para los casos que sea necesario.

Fotografía: pueden ser entregadas en original para ser digitalizadas, de lo contrario se deben digitalizar con una resolución igual o superior a 300 dpi para imágenes a color y 600 para escala de grises. Los formatos de las imágenes pueden ser TIFF, PSD o JPG, y deben cumplir con las características expresadas en el punto anterior (figuras).

Planimetría: se debe entregar la planimetría original en medio digital, en lo posible en formato CAD, y sus respectivos archivos de plumas o en PDF; de no ser posible, se deben hacer impresiones en tamaño carta con las referencias de los espacios mediante numeración y lista adjunta. Deben tener escala gráfica, escala numérica, norte, coordenadas y localización. En lo posible, no deben contener textos, achurados o tramas.

Para más detalles, consultar el documento RevArq Parámetros para Autores Descripción en el portal web de la Revista de Arquitectura (Bogotá)

\section{Beneficios}

Como reconocimiento a los autores, se les hará envío postal de dos ejemplares de la edición impresa sin ningún costo y entregada en la dirección consignada en el formato de hoja de vida (RevArq FP01); adicionalmente, se enviará el vínculo para la descarga de la versión digital.

También se enviará una constancia informativa en la que se relaciona a publicación del artículo y, de manera opcional, se pueden detallar las fechas del proceso editorial y el arbitraje realizado. 
La selección de revisores se realiza de acuerdo con los siguientes criterios:

- Afinidad temática.

- Formación académica.

- Experiencia investigativa y profesional.

- Producción editorial en revistas similares o en libros resultado de investigación.

El proceso de arbitraje se basa en los principios de equidad e imparcialidad, y en los criterios de calidad y pertinencia.

El desarrollo de la revisión se realiza según el formato (RevArq FP10 Evaluación de artículos) y las observaciones que el revisor considere necesarias en el cuerpo del artículo. En cualquiera de los conceptos que emita el revisor (Aceptar, Publicable con modificaciones, Reevaluable o No publicable), y como parte de la labor formativa y de comunidad académica, el revisor hará sugerencias para mejorar el documento. El revisor podrá solicitar una nueva relectura del artículo después de los ajustes realizados por el autor.

El revisor también deberá diligenciar el formato RevArq FP01 Hoja de Vida, con el fin de certificar y soportar el proceso de revisión ante los SIR que así lo soliciten.

En el proceso de arbitraje se emplea el método doble ciego, los nombres del revisor no serán conocidos por el autor y viceversa. Con el fin de garantizar el anonimato del autor, al artículo postulado se le han podido suprimir nombres, instituciones o imágenes que puedan ser asociadas de manera directa al autor.

Aunque se procura el anonimato, una vez recibida la invitación como par revisor del artículo, el revisor debe cerciorarse de que no exista conflicto de intereses (CDI) o alguna limitante que afecte la revisión o que pueda ser vista como tal (lazos familiares, amistad o enemistad, vínculos contractuales o laborales, posiciones éticas, etc.), de presentarse esta situación se notificara al editor. (Ver modelo RevArq FP06 CDI).

Dada la confidencialidad del proceso de revisión, y considerando los derechos de autor y de propiedad intelectual que pueda haber sobre el material que se entrega, el revisor se compromete a mantener en absoluta reserva su labor, a limitar el uso de la obra entregada solo para el propósito designado y a devolver la documentación remitida una vez concluya la actividad.

El tiempo establecido para las revisiones de pares es de máximo un mes a partir de la confirmación de la recepción de la documentación. Ese plazo podrá ser modificado de mutuo acuerdo entre el editor y el revisor, siempre y cuando no afecte la periodicidad de la revista, la impresión o el tiempo para emitir una respuesta al autor.

Los revisores se acogerán a "COPE Ethical Guidelines for Peer Reviewers" de COPE.

\section{Beneficios}

Como retribución a los revisores se les hará envío postal de un ejemplar de la edición impresa sin ningún costo y entregada en la dirección consignada en el formato de hoja de vida. También, si es de interés para el revisor, podrá hacer la solicitud de alguna de las publicaciones editadas y presentes en el catálogo de publicaciones de la UNIVERSIDAD CATÓLICA DE COLOMBIA, previa aprobación de la Editorial y sujeto a la disponibilidad.

Si lo desea tendrá derecho a una constancia de la colaboración en la revisión de artículos, la cual solo contendrá el periodo en el cua se realizó la actividad. También tendrá la posibilidad de aceptar o no la publicación de su nombre, nacionalidad y nivel máximo de formación en la página web de la Revista de Arquitectura (Bogotá) en su calidad de colaborador.

\section{A Proceso de revisión por pares}

Luego de la postulación del artículo, el editor de la Revista de Arquitectura (Bogotá) selecciona y clasifica los artículos que cumplen con los requisitos establecidos en las directrices para los autores. El editor podrá rechazar en primera instancia artículos, sin recurrir a un proceso de revisión, si los considera de baja calidad o por presentar evidencias de faltas éticas o documentación incompleta.

Los artículos se someterán a un primer dictamen del editor, de los editores de sección y del Comité Editorial, teniendo en cuenta:

- Afinidad temática, relevancia del tema y correspondencia con las secciones definidas.

- Respaldo investigativo.

- Coherencia en el desarrollo del artículo, así como una correcta redacción y ortografía.
- Relación entre las figuras y tablas con el texto del artículo.

En esta revisión se verificará el nivel de originalidad mediante el uso de software especializado (Ithenticate o similar) y recursos digitales existentes para tal fin, también se observará la coherencia y claridad en los apartados del documento (modelo IMRYD) la calidad de las fuentes y la adecuada citación, esto quedará consignado en el formato (RevArq FP09 Revisión de artículos); esta información será cargada a la plataforma de gestión editorial y estará a disposición del autor.

En caso de que el artículo requiera ajustes preliminares, será devuelto al autor antes de ser remitido a revisores. En este caso, el autor tendrá veinte días para remitir nuevamente el texto con los ajustes solicitados.

Después de la preselección se asignan mínimo dos revisores especializados, quienes emitirán su concepto utilizando el formato (RevArq FP10 Evaluación de artículos) y las anotaciones que consideren oportunas en el texto; en esta etapa se garantizará la confidencialidad y el anonimato de autores y revisores (modalidad doble ciego)

Del proceso de revisión se emite uno de los siguientes conceptos que será reportado al autor:

- Aceptar el envío: con o sin observaciones.

- Publicable con modificaciones: se podrá sugerir la forma más adecuada para una nueva presentación, el autor puede o no aceptar las observaciones según sus argumentos. Si las acepta, cuenta con quince días para realizar los ajustes pertinentes.

- Reevaluable: cumple con algunos criterios y debe ser corregido. Es necesario hacer modificaciones puntuales y estructurales al artículo. En este caso, el revisor puede aceptar o rechazar hacer una nueva lectura del artículo luego de ajustado.

- No publicable: el autor puede volver a postular el artículo e iniciar nuevamente el proceso de arbitraje, siempre y cuando se evidencien los ajustes correspondientes.

En el caso de presentarse diferencias sustanciales y contradictorias en los conceptos sobre la recomendación del revisor, el editor remitirá el artículo a un revisor más o a un miembro del Comité Editorial quien podrá actuar como tercer árbitro, con el fin de tomar una decisión editorial sobre la publicación de artículo.

Los autores deberán considerar las observaciones de los revisores o de los editores, y cada corrección incorporada u omitida debe quedar justificada en el texto o en una comunicación adjunta. En el caso que los autores omitan las indicaciones realizadas sin una argumentación adecuada, el artículo será devuelto y no se dará por recibido hasta que no exista claridad al respecto. El editor respetará la independencia intelectual de los autores y a estos se les brindará el derecho de réplica en caso de que los artículos hayan sido evaluados negativamente y rechazados. Los autores, con su usuario y contraseña, podrán ingresar a la plataforma de Gestión Editorial, donde encontrarán los conceptos emitidos y la decisición sobre el artículo.

El editor y el Comité Editorial se reservan el derecho de aceptar o no la publicación del material recibido. También se reservan el derecho de sugerir modificaciones de forma, ajustar las palabras clave o el resumen y de realizar la corrección de estilo. El autor conocerá la versión final del texto antes de la publicación oficial del mismo.

Cuando un artículo es aceptado para su publicación, el autor debe firmar la autorización de reproducción (RevArq FP03 Autorización reproducción). Para más información ver: Política de derechos de autor

\section{Notas aclaratorias:}

La Revista de Arquitectura (Bogotá) busca el equilibrio entre las secciones, motivo por el cual, aunque un artículo sea aceptado o continúe en proceso de revisión, podrá quedar aplazado para ser publicado en un próximo número; en este caso, el autor estará en la posibilidad de retirar la postulación del artículo o de incluirlo en el banco de artículos del próximo número.

El editor y los editores de sección de la Revista de Arquitectura (Bogotá) son los encargados de establecer contacto entre los autores y revisores, ya que estos procesos se realizan de manera anónima.
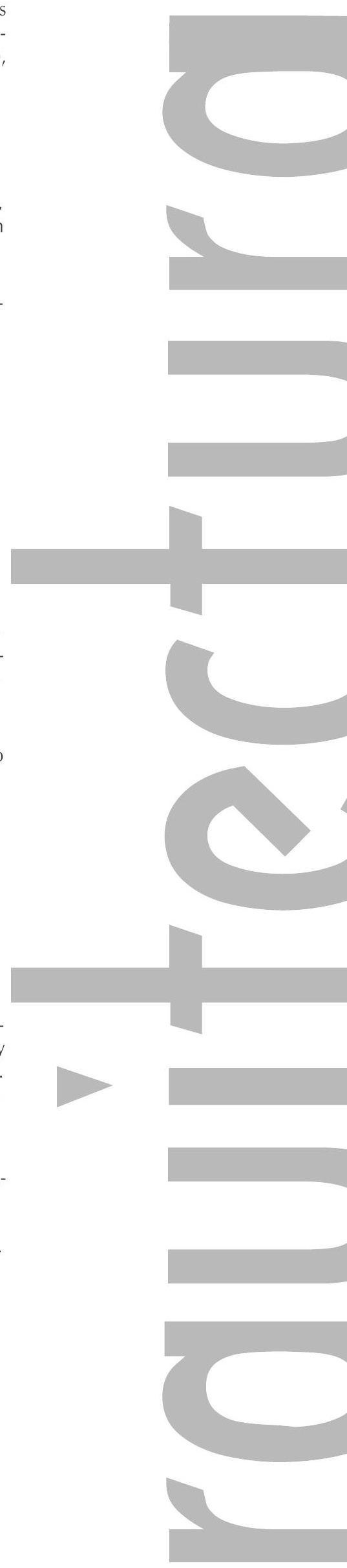

\section{.}

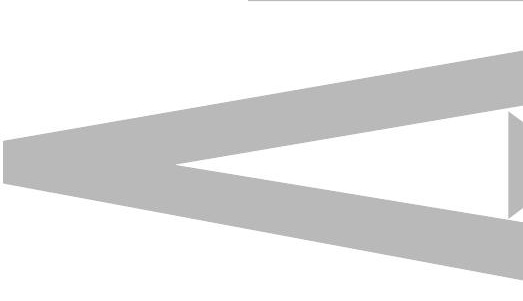


Los artículos científicos como herramienta de aprendizaje en las escuelas de arquitectura

نं Scientific articles as a learning tool in architecture schools

$\ll \quad$ Os artigos científicos como ferramenta de aprendizagem

nas escolas de arquitetura

Carolina Rodriguez-Ahumada

Paisaje urbano y espacio público como expresión 으 de la vida cotidiana

Urban landscape and public space as an expression of everyday life

نั Paisagem urbana e espaço público como expressão da vida cotidiana

Habitar la quebrada: conformación de gradientes en las trazas 을 vernaculares de los sectores altos de Valparaíso

Inhabiting the ravine: Gradient configuration in the vernacular layouts of the

¿ higher sectors of Valparaíso

Habitar a quebrada: conformação de níveis nos traçados vernaculares dos setores altos de Valparaíso

\section{Omar Eduardo Canete-Islas}

Juan Luis Moraga-Lacoste

Felipe Mateo López-Flores

Láminas cilíndricas en la arquitectura colombiana del siglo $X X$ Cylindrical shells in Colombian architecture in the 20th century

Estruturas laminares cilíndricas na arquitetura colombiana do século $X X$ 这 Jorge Galindo-Díaz

Retórica simbólica en el espacio arquitectónico. Una mirada antropológica de la casa en la sobremodernidad

in Symbolic Rhetoric in the Architectural Space: An Anthropological View of the

ن House in the Age of Supermodernity

Retórica simbólica no espaço arquitetônico. Um olhar antropológico da casa na sobremodernidade

\section{Eska Elena Solano-Meneses}

Ecoenvolventes: análisis del uso de fachadas ventiladas en clima ㅈ cálido-húmedo

نं Eco-friendly coverings: Analysis of the use of ventilated facades in hot, humid

ن⿺ weather

Ecoenvolventes: análise do uso de fachadas ventiladas em clima quente úmido

Sara Luciani-Meía

Rodrigo Velasco-Gómez

Roland Hudson

Estrategias metodológicas de análisis urbano frente al cambio œ climático. Matriz para el diseño adaptativo en asentamientos $\stackrel{\infty}{\text { informales }}$

Methodological strategies for urban analysis in the face of climate change. An adaptive design matrix for informal settlements

Estratégias metodológicas de análise urbana ante mudanças climáticas. Matriz para o desenho adaptativo em assentamentos informais

Adriana Patricia López-Valencia

Muro panel térmico estructural compuesto en guadua y - cartónModelo experimental aplicado al clima de la zona cafetera

․ Structural thermal panel wall composed of bamboo and cardboard.

Experimental model applied to the climate of the Coffee Region

$\ltimes$ Muro painel térmico estrutural composto de bambu e papelão. Modelo experimental aplicado ao clima da zona cafeeira

\section{Renato Cassandro-Cajiao}

Continuidad y transformaciones de modelos pedagógicos en la École Polytechnique (1867-1910)

으 Continuity and transformations of teaching models at the École Polytechnique

二 (1867-1910)

ن Continuidade e transformações de modelos pedagógicos na École

¿ Polytechnique (I867-1910) 